\title{
Adjunct Therapies During Mechanical Ventilation: Airway Clearance Techniques, Therapeutic Aerosols, and Gases
}

\author{
Richard H Kallet MSc RRT FAARC
}

\author{
Introduction \\ Airway Clearance Techniques \\ Intrapulmonary Percussive Ventilation \\ Mechanical Insufflation-Exsufflation \\ Aerosolized Medications \\ Pressurized Metered-Dose Inhalers \\ Nebulizers \\ Aerosolized Antibiotics \\ Aerosolized Prostaglandins and Inhaled Nitric Oxide \\ Aerosolized Anticoagulants and Oxygen Radical Scavengers \\ Heliox \\ Summary
}

\begin{abstract}
Mechanically ventilated patients in respiratory failure often require adjunct therapies to address special needs such as inhaled drug delivery to alleviate airway obstruction, treat pulmonary infection, or stabilize gas exchange, or therapies that enhance pulmonary hygiene. These therapies generally are supportive in nature rather than curative. Currently, most lack high-level evidence supporting their routine use. This overview describes the rationale and examines the evidence supporting adjunctive therapies during mechanical ventilation. Both mechanistic and clinical research suggests that intrapulmonary percussive ventilation may enhance pulmonary secretion mobilization and might reverse atelectasis. However, its impact on outcomes such ICU stay is uncertain. The most crucial issue is whether aerosolized antibiotics should be used to treat ventilatorassociated pneumonia, particularly when caused by multi-drug resistant pathogens. There is encouraging evidence from several studies supporting its use, at least in individual cases of pneumonia non-responsive to systemic antibiotic therapy. Inhaled pulmonary vasodilators provide at least short-term improvement in oxygenation and may be useful in stabilizing pulmonary gas exchange in complex management situations. Small uncontrolled studies suggest aerosolized heparin with $\mathrm{N}$-acetylcysteine might break down pulmonary casts and relieve airway obstruction in patients with severe inhalation injury. Similar low-level evidence suggests that heliox is effective in reducing airway pressure and improving ventilation in various forms of lower airway obstruction. These therapies generally are supportive and may facilitate patient management. However, because they have not been shown to improve patient outcomes, it behooves clinicians to use these therapies parsimoniously and to monitor their effectiveness carefully. Key words: high-frequency percussive ventilation; intrapulmonary percussive ventilation; inhaled nitric oxide; aerosolized prostacyclin; aerosolized heparin; metered-dose inhalers; heliox. [Respir Care 2013;58(6):1053-1071. (C) 2013 Daedalus Enterprises]
\end{abstract}

\footnotetext{
Mr Kallet is affiliated with Respiratory Care Services, Department of Anesthesia, University of California, San Francisco, at San Francisco General Hospital, San Francisco, California.

Mr Kallet presented a version of this paper at the 51st RESPIRATORY CARE Journal Conference, "Adult Mechanical Ventilation in Acute Care: Issues and Controversies," held September 7 and 8, 2012, in St Petersburg, Florida.
}

The author has disclosed no conflicts of interest.

Correspondence: Richard H Kallet MSc RRT FAARC, Respiratory Care Services, San Francisco General Hospital, NH GA-2, 1001 Potrero Avenue, San Francisco CA 94110. E-mail: rich.kallet@ucsf.edu.

DOI: $10.4187 /$ respcare. 02217 


\section{Introduction}

Two primary goals of mechanical ventilation are to establish adequate arterial oxygenation and carbon dioxide excretion, and to assume the power of breathing either to normalize or minimize respiratory muscle work load. Generally, these goals can be accomplished with standard ventilator manipulations alone. However, critically ill patients in respiratory failure often require direct pulmonary delivery of drugs, as well as inhaled medical gases, in order to reverse the underlying pathology and/or to stabilize gas exchange. Also, other adjunctive therapies are used either to improve pulmonary mechanics or facilitate bronchial hygiene.

In this paper I will review various adjunctive therapies frequently incorporated during mechanical ventilation. These will include a review of mechanically enhanced secretion clearance techniques, as well as various aerosol delivery devices. This will be followed by reviews of: inhaled antibiotics for ventilator-associated pneumonia (VAP); selective pulmonary vasodilators to improve gas exchange and reduce pulmonary vascular resistance in patients with ARDS, or pulmonary hypertension; anticoagulants/radical oxygen species scavengers in the treatment of ARDS from inhalation injury; and heliox for patients with respiratory failure from severe airway obstruction. Each therapy is discussed in terms of its rationale and level of evidence. This may assist clinicians in evaluating whether these therapies should be incorporated, and under what circumstances they should be considered.

\section{Airway Clearance Techniques}

\section{Intrapulmonary Percussive Ventilation}

Applying high-frequency oscillations to the airways enhances secretion clearance when interfaced with either spontaneous breathing ${ }^{1}$ or conventional mechanical ventilation. ${ }^{2}$ The most popular has been high-frequency percussive ventilation ${ }^{3}$ or intrapulmonary percussive ventilation (IPV). ${ }^{2}$ IPV has been the object of particular interest in inhalational injury, $2,4,5$ which is characterized by damaged mucociliary function, extensive sloughing of airway epithelial cells, and cast formation resulting in severe airway obstruction, atelectasis, and pneumonia. The mechanism by which IPV may promote pulmonary secretion clearance is its asymmetrical flow pattern, whereby expiratory flow exceeds inspiratory flow to propel secretions forward (Fig. 1). ${ }^{6}$ Animal models of excessive secretion production suggest that incorporating a higher peak expiratory to peak inspiratory flow ratio of approximately $4: 1$ (ie, a peak expiratory flow of $3.8 \mathrm{~L} / \mathrm{s}$ and a peak inspiratory flow of $1.3 \mathrm{~L} / \mathrm{s}$ ) at a frequency of $14 \mathrm{~Hz}$ substantially increases the

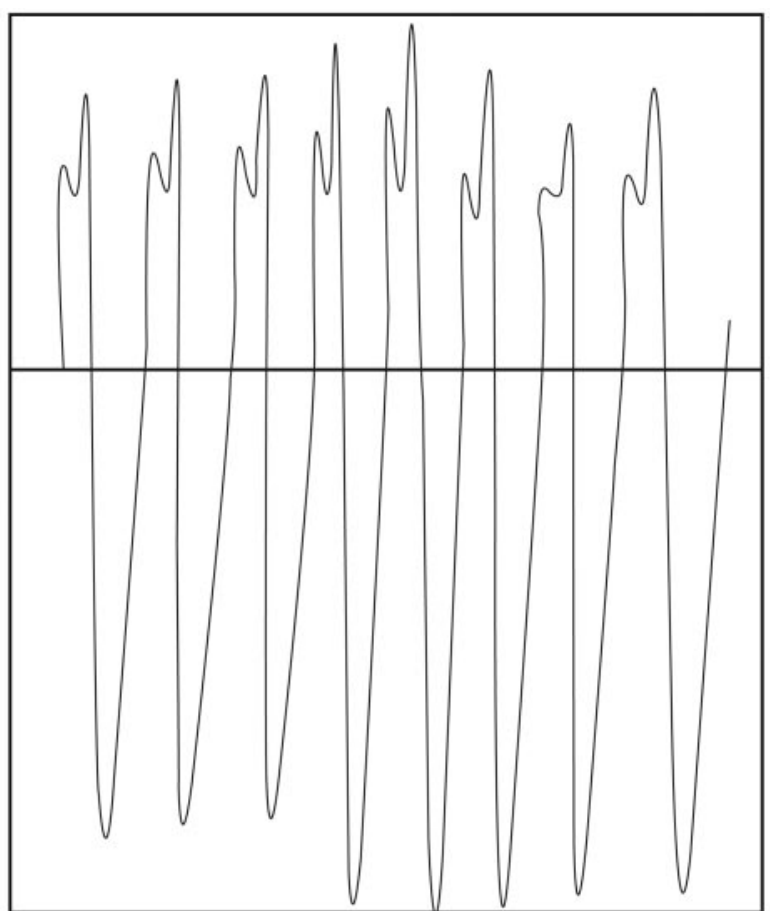

Fig. 1. Representation of a high-frequency, asymmetrical flow pattern. Expiratory flows exceed inspiratory flow by a ratio of at least $4: 1$, so that pulmonary secretions sheared from the airway wall will tend to be propelled toward the central airways rather than deeper into the lung periphery.

rate of secretion clearance and augments the effects of postural drainage. ${ }^{7}$

Critically ill patients often have impaired secretion clearance for several reasons, including the effects of oxygen therapy on mucociliary function, hypersecretion from infection, impaired cough in the presence of an artificial airway, or muscle weakness. The effectiveness of coughing and propelling secretions forward is based upon several factors. Probably the most important is the gas-liquid interaction, whereby a gas stream flowing over a mucus layer creates shear forces. ${ }^{1}$ These forces loosen secretions from the airway wall and propel them either deeper into the lung periphery, or toward the central airways where they can be suctioned.

As mentioned above, this is determined by asymmetric flow relationships whereby peak expiratory flow must exceed inspiratory flow in order to propel secretions cephalad. This is referred to as "2-phase, gas liquid flow" and consists of 3 features in mucus-filled airways: bubble flow, plug flow, and annular flow (Fig. 2) ${ }^{8}$ Bubble flow occurs in the presence of mucus plugging, whereby low-flow gas passes through the obstruction as small bubbles. As airflow increases further, the bubbles grow in size and coalesce, breaking apart the mucus wall (plug flow), eventually creating a patent channel through the plug (annular flow). As gas flow velocity increases, the mucus layer 

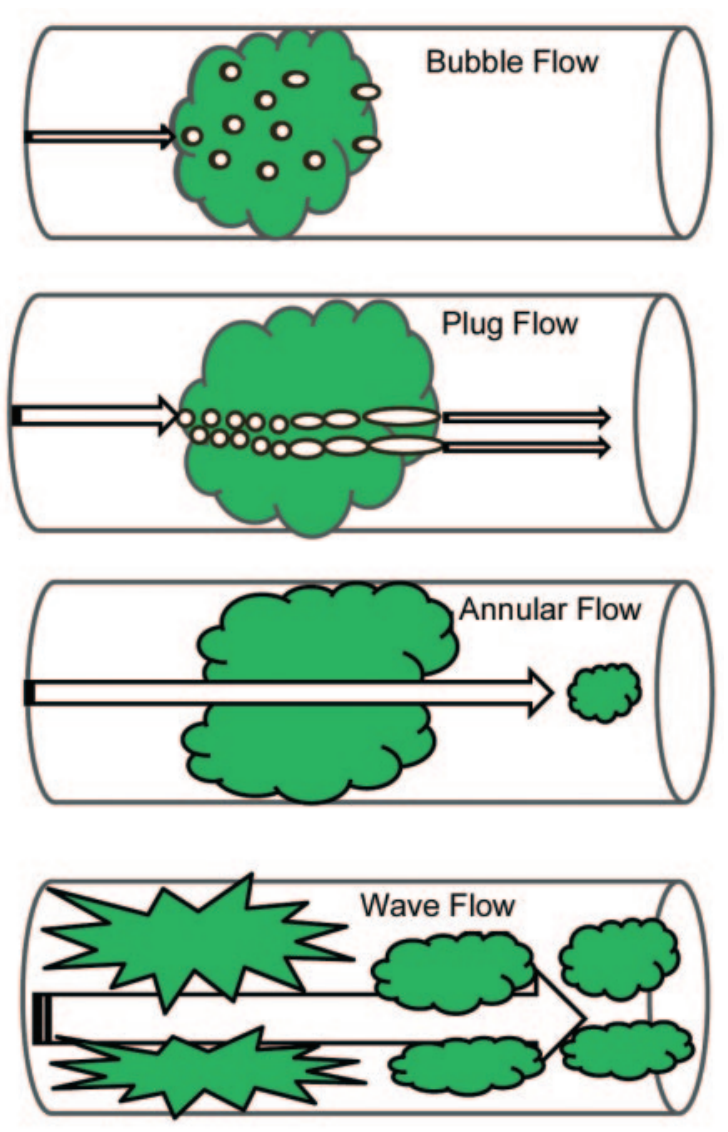

Fig. 2. Features of the "2-phase, gas liquid flow" mechanism by which mucus plugs are thought to be dislodged from the airways. Individual gas bubbles first penetrate the plug (bubble flow); as more penetrate the plug, these bubbles tend to coalesce into larger bubbles (plug flow) until they form a distinct channel through the plug, allowing for greater gas velocity (annular flow). As the gas velocity increases through the channel, so does the frictional force at the gas/liquid interface. This results in the development first of ripples and then waves across the mucus surface, until sufficient frictional or shear forces dislodge the plug from the airway wall (wave flow).

becomes more unstable, first forming ripples and waves (wave flow) to a sufficient level that shear forces then peel away the mucus layer from the airway wall (as occurs during a forceful cough). ${ }^{8}$

The rheologic characteristics of mucus also interact in complex ways with gas flow to determine mucus dynamics in the airways. These include the viscous and elastic properties of the mucus, as well as the thickness of the mucus layer. ${ }^{8}$ There is evidence suggesting that application of airway oscillations between $12-22 \mathrm{~Hz}$ for between 15-30 min acts as a "physical mucolytic" capable of altering the rheologic properties and promoting mobilization. ${ }^{9}$

Applying high-frequency oscillations either directly to the airway opening or to the chest wall appears to enhance secretion clearance, compared to no therapeutic intervention. ${ }^{10,11}$ However, most studies have not been done on patients requiring mechanical ventilation. Although comparisons between oscillatory devices and standard chest physical therapy (CPT) techniques have produced generally positive results, this has not yet been consistently demonstrated across all studies, at least in respect to outcome measures (Table 1). For example, in a large prospective randomized controlled trial (RCT), Clinkscale et al ${ }^{12}$ reported no difference between a traditional CPT regimen and chest wall oscillatory therapy in either ICU or hospital stay among adults with various pulmonary diseases.

In contrast, several studies suggest that IPV may be superior to traditional CPT, particularly in regard to pulmonary hygiene. Toussaint et $\mathrm{al}^{1}$ reported significantly better secretion clearance (ie, a $40 \%$ increase in sputum weight) with IPV in a small randomized crossover trial in patients with Duchenne muscular dystrophy and excessive sputum production. Similar findings of significantly improved postoperative sputum production also were reported by Lucangelo et $\mathrm{al}^{13}$ when IPV was applied to patients undergoing pulmonary resection. Although total postoperative sputum production was not different between treatment groups, patients treated with IPV cleared a greater amount of secretions more rapidly (ie, $72 \%$ of their total sputum was cleared by the fourth postoperative day, compared to $46 \%$ in the group managed with CPAP). Antonaglia et al ${ }^{14}$ compared IPV to standard CPT in 40 patients with COPD receiving noninvasive ventilation (NIV) in an RCT. They found that patients who received twice-per-day IPV therapy had improved oxygenation and carbon dioxide excretion, as well as decreased ICU stay. However, sputum production was not measured during the study and the incidence of pneumonia was not different. Therefore, the reason for improved ICU stay was unclear.

IPV has also been reported to be an effective treatment for atelectasis that is refractory to traditional therapies. In a small randomized trial, Deakins and Chatburn ${ }^{15}$ found that pediatric patients who received IPV had improved atelectasis scores by chest radiograph within 3 days, compared to no improvement among those receiving a standard CPT regimen for 6 days. Likewise, Reper and van Looy ${ }^{16}$ described 10 non-intubated patients with smoke inhalation injury and respiratory distress in whom the addition of IPV to standard CPT resolved atelectasis and improved $\mathrm{P}_{\mathrm{aO}_{2}} / \mathrm{F}_{\mathrm{IO}_{2}}$. Of particular interest was the fact that bronchoscopy had failed to treat atelectasis effectively.

Tsuruta et $\mathrm{al}^{17}$ superimposed IPV with traditional mechanical ventilation to treat compression atelectasis prospectively in a series of 10 obese patients with various etiologies of acute respiratory failure. Improvement in atelectasis was confirmed by either chest radiograph or chest computed tomography. However, these improvements were in the context of management using modest levels of PEEP 


\section{Adjunct Therapies During Mechanical Ventilation}

Table 1. Studies on IPV Examining Secretion Clearance and Reversal of Atelectasis in the ICU Setting

\begin{tabular}{|c|c|c|c|c|c|c|}
\hline First Author & Year & $\begin{array}{l}\text { Study } \\
\text { Type }\end{array}$ & $\begin{array}{l}\text { Level of } \\
\text { Evidence }\end{array}$ & $n$ & Setting/Protocol & Trial Results \\
\hline Clinkscale $^{12}$ & 2012 & RCT & II & 280 & $\begin{array}{l}\text { Adult ICU } \\
\text { Intubated and non-intubated patients } \\
\text { with a variety of pulmonary } \\
\text { diseases }\end{array}$ & $\begin{array}{l}\text { No benefit } \\
\text { No difference in ICU or hospital stay, } \\
\text { compared to traditional CPT } \\
\text { Tendency towards higher discomfort with } \\
\text { traditional CPT }\end{array}$ \\
\hline Toussaint $^{1}$ & 2003 & $\begin{array}{l}\text { Randomized } \\
\text { crossover } \\
\text { trial }\end{array}$ & II-B & 8 & $\begin{array}{l}\text { Duchenne muscular dystrophy } \\
\text { Assisted secretion clearance } \\
\text { techniques vs assisted secretion } \\
\text { clearance techniques plus IPV }\end{array}$ & $\begin{array}{l}\text { Benefit only in patients with mucus } \\
\text { hypersecretion }(>30 \mathrm{~mL} / \mathrm{d}) \\
\text { Significantly } \uparrow \text { weight of collected } \\
\text { sputum and significantly } \downarrow \text { airways } \\
\text { resistance following IPV }\end{array}$ \\
\hline Lucangelo $^{13}$ & 2009 & RCT & II & 44 & $\begin{array}{l}\text { Patients undergoing thoracotomy for } \\
\text { partial lung resection } \\
\text { Non-dependent lung was ventilated } \\
\text { either with IPV or CPAP } \\
\text { Dependent lung was ventilated with } \\
\text { continuous mandatory ventilation } \\
\text { in both groups }\end{array}$ & $\begin{array}{l}\text { Benefit } \\
\uparrow \mathrm{P}_{\mathrm{aO}} \text { in IPV group prior to re-expansion } \\
\text { of non-dependent lung (suggests less } \\
\text { intraoperative de-recruitment) } \\
\text { Significantly } \downarrow \text { time to mobilize more } \\
\text { secretions in IPV group } \\
\downarrow \text { time to hospital discharge in IPV group } \\
\text { Significantly } \uparrow \text { secretion production in } \\
\text { subset of patients with COPD }\end{array}$ \\
\hline Antonaglia $^{14}$ & 2006 & $\mathrm{RCT}$ & II & 40 & $\begin{array}{l}\text { Patients with COPD receiving NIV } \\
\text { via helmet received either IPV or } \\
\text { CPT } \\
\text { Secondary analysis vs historical } \\
\text { control group who received NIV } \\
+ \text { CPT }\end{array}$ & $\begin{array}{l}\text { Benefit } \\
\text { At ICU discharge, IPV group had } \\
\text { significantly } \uparrow \mathrm{P}_{\mathrm{aO}_{2}} / \mathrm{F}_{\mathrm{IO}_{2}, \downarrow \mathrm{P}_{\mathrm{aCO}_{2}} \text {, }}, \quad \text { need for NIV, and } \downarrow \text { ICU stay }\end{array}$ \\
\hline Deakins ${ }^{15}$ & 2002 & $\begin{array}{l}\text { Case series } \\
\text { and RCT }\end{array}$ & $\begin{array}{l}\text { IV } \\
\text { II }\end{array}$ & $\begin{array}{l}46 \\
12\end{array}$ & $\begin{array}{l}\text { General pediatric ICU population } \\
\text { Retrospective review of } 46 \text { patients } \\
\text { who received IPV } \\
\text { RCT of } 12 \text { patients comparing IPV } \\
\text { to CPT every } 4 \mathrm{~h} \text { for treatment of } \\
\text { atelectasis }\end{array}$ & $\begin{array}{l}\text { Benefit } \\
\text { Significant } \downarrow \text { in atelectasis score over } 6 \mathrm{~d} \\
\text { in retrospective study } \\
\text { Significant } \downarrow \text { in atelectasis score in IPV } \\
\text { group over } 3 \mathrm{~d} \text {, vs no improvement in } \\
\text { CPT group }\end{array}$ \\
\hline Reper $^{16}$ & 2013 & $\begin{array}{l}\text { Prospective } \\
\text { uncontrolled } \\
\text { study }\end{array}$ & IV & 10 & $\begin{array}{l}\text { Smoke inhalation confirmed via } \\
\text { bronchoscopy } \\
\text { IPV added to conventional therapy } \\
\text { after failure of repeated } \\
\text { therapeutic bronchoscopy to } \\
\text { improve either atelectasis or } \\
\text { oxygenation }\end{array}$ & $\begin{array}{l}\text { Benefit } \\
\text { Significantly } \uparrow \mathrm{P}_{\mathrm{aO}_{2}} / \mathrm{F}_{\mathrm{IO}_{2}} \text {, trend towards } \\
\quad \text { improved } \mathrm{P}_{\mathrm{aCO}} \\
\text { Complete resolution of atelectasis: median } \\
\quad \text { resolution time } 36 \mathrm{~h}\end{array}$ \\
\hline Tsuruta $^{17}$ & 2006 & $\begin{array}{l}\text { Prospective } \\
\text { uncontrolled } \\
\text { study }\end{array}$ & IV & 10 & $\begin{array}{l}\text { Obese patients with acute } \\
\text { respiratory failure due to } \\
\text { compression atelectasis } \\
\text { unresponsive to at least } 12 \mathrm{~h} \text { of } \\
\text { conventional mechanical } \\
\text { ventilation } \\
\text { IPV interfaced with conventional } \\
\text { mechanical ventilation for } 24 \mathrm{~h}\end{array}$ & $\begin{array}{l}\text { Benefit } \\
\text { Significantly } \uparrow \mathrm{P}_{\mathrm{aO}_{2}} / \mathrm{F}_{\mathrm{IO}_{2}} \text { from } 3-24 \mathrm{~h} \\
\quad \text { after initiating IPV } \\
\text { Significantly } \uparrow \text { dynamic compliance } \\
\downarrow \text { atelectasis in all } 10 \text { patients via x-ray, } \\
\text { and in } 7 \text { patients via CT, and complete } \\
\text { resolution of dorsal atelectasis in } 5 \\
\text { patients }\end{array}$ \\
\hline Clini $^{18}$ & 2006 & RCT & II & 46 & $\begin{array}{l}\text { Prolonged weaning in patients with } \\
\text { various cardiopulmonary diseases } \\
\text { IPV plus CPT vs CPT alone } \\
\text { Evaluated after } 15 \mathrm{~d} \text { of therapy }\end{array}$ & $\begin{array}{l}\text { Benefit } \\
\text { IPV group had } \uparrow \mathrm{P}_{\mathrm{aO}} / \mathrm{F}_{\mathrm{IO}_{2}} \text { and maximal } \\
\quad \text { expiratory pressure, and } 50 \% \text { lower } \\
\text { incidence of pneumonia } \\
\text { No difference in need for bronchoscopy to } \\
\text { remove excessive secretions }\end{array}$ \\
\hline \multicolumn{7}{|c|}{$\begin{array}{l}\text { IPV }=\text { intrapulmonary percussive ventilation } \\
\text { RCT }=\text { randomized controlled trial } \\
\text { CPT }=\text { chest physiotherapy } \\
\text { NIV = noninvasive ventilation }\end{array}$} \\
\hline
\end{tabular}


(mean of $8 \mathrm{~cm} \mathrm{H}_{2} \mathrm{O}$, range 5-12 $\mathrm{cm} \mathrm{H}_{2} \mathrm{O}$ ) for up to $12 \mathrm{~h}$, so that the attribution of improvements to IPV is not completely clear. Clini et al ${ }^{18}$ studied whether adding twicedaily IPV to a standard CPT regimen would improve outcomes in patients requiring prolonged weaning in a randomized trial. Although the incidence of atelectasis and need for bronchoscopy was not different, the incidence of nosocomial pneumonia was significantly less in patients receiving supplemental IPV therapy.

Despite the theoretical advantages of IPV for enhanced secretion clearance, and the positive results of the aforementioned studies, another randomized trial comparing IPV to either conventional or lung-protective ventilation did not find significant differences in infectious complications, at least in patients with thermal injuries. ${ }^{19}$ However, secretion clearance was neither monitored nor an end point in these studies.

Interpreting the usefulness of IPV as an adjunct therapy to enhance secretion clearance during mechanical ventilation is problematic for a variety of reasons including:

- Many studies were done in patients who did not require mechanical ventilation, or IPV was used as the primary mode of ventilation.

- Relatively small sample sizes

- Heterogeneity of patient populations studied (eg, cystic fibrosis, inhalation injury, COPD, neuromuscular disease)

- The monitoring of different variables of interest and end points studied

These factors stymie attempts to evaluate the relative usefulness of interfacing IPV therapy during conventional mechanical ventilation. Furthermore, tracheobronchitis from poor humidification has long been a concern with IPV therapy, so that a heated humidifier should be used to condition the inspiratory gases. Despite these limitations, interfacing IPV with pressure-regulated modes may be worth considering in patients with inhalation injuries, copious thick secretions, and, perhaps, atelectasis refractory to moderate levels of PEEP. However, it should be kept clearly in mind that IPV has not yet been demonstrated to improve clinically meaningful outcomes.

Another aspect of IPV has been the relatively consistent findings of improved oxygenation in patients with ARDS. ${ }^{5,20-23}$ It may be a particularly effective means of improving oxygenation in patients with ARDS and traumatic brain injury, wherein the application of sufficient levels of PEEP needed to recruit the lungs might cause undesirable increases in intracranial pressure. ${ }^{5,21}$ This has been attributed largely to the effects of high-frequency oscillation in improving intra-pulmonary gas distribution through several mechanisms, including the effects of tur- bulent flow on longitudinal gas dispersion (the Taylor effect), pendelluft motion, asymmetrical gas velocity profiles within the airways, and cardiac mixing, as well as the traditional mechanisms of bulk gas flow and diffusion in the alveolar zone. ${ }^{24}$

However, it must be recognized that these results emanate from small, uncontrolled, retrospective studies, wherein there is a lack of systematic application of standard therapies such as PEEP, clearly defined criteria used to decide whether or not conventional therapies had indeed failed, and systematic, protocol-driven application of IPV. For example, in the study by Velmahos et $\mathrm{al}^{22}$ the improvement in $\mathrm{P}_{\mathrm{aO}} / \mathrm{F}_{\mathrm{IO}_{2}}$ with IPV coincided with a significant increase in mean airway pressure, compared to conventional ventilation with pressure and volume control modes (35-63\%, respectively). A salient but nonsignificant trend toward increased PEEP and mean airway pressure also was reported by Salim et al. ${ }^{21}$

Although only low level evidence supports the use of IPV to improve oxygenation in patients with ARDS, the concept of superimposing a percussive ventilation pattern during traditional pressure-regulated ventilation is intriguing, as it may utilize alternative methods of improving intrapulmonary gas mixing that may allow for improved oxygenation at lower levels of traditional support (eg, tidal volume, rate, and PEEP requirements). This potentially may be useful in the maintenance of lung-protective ventilation goals in ARDS. However, this remains only conjecture that would require affirmation from an appropriately sized prospective randomized controlled study before it could be advocated as standard practice.

\section{Mechanical Insufflation-Exsufflation}

Mechanical insufflation-exsufflation is an artificial cough technique whereby the lungs are mechanically inflated with positive pressure, followed by the sudden application of negative pressure to the airway. Although the technique has been used since the $1950 \mathrm{~s},{ }^{25}$ it was only in the early 1990s that it became widely used when the Cough Assist In-Exsufflator (Phillips/Respironics, Murrysville, Pennsylvania.) became commercially available. Mechanical cough-assist devices share mechanisms of action similar to IPV, in that both create shear forces in the airway that help mobilize secretions. Typically, positive and negative pressure swings of $30-40 \mathrm{~cm} \mathrm{H}_{2} \mathrm{O}$ are applied in repetitions of 3-5 maneuvers to mobilize secretions. ${ }^{26}$ This therapy has been used primarily to promote pulmonary hygiene in patients with neuromuscular diseases. ${ }^{27}$

Major reasons cited for extubation failure in patients who have successfully passed a spontaneous breathing trial are ineffective cough and/or the presence of copious secretions. ${ }^{28,29}$ Moreover, patients who fail a trial of extu- 
bation often require a prolonged ICU as well as hospital stay, and also are at greater risk for hospital mortality. ${ }^{30}$

NIV has been used to treat respiratory distress following extubation, but has produced inconsistent results. ${ }^{31}$ However, particular attention has not focused on the role of secretion clearance in preventing reintubation in these patients. Two recent studies ${ }^{32,33}$ investigated incorporating mechanical cough-assist devices with NIV to prevent extubation failure. In a small, prospective study, ${ }^{32}$ patients with neuromuscular disease recovering from acute respiratory failure were managed during the post-extubation period with NIV and mechanical cough-assist therapy. These patients were compared to historical controls who received standard medical therapy. Whereas all patients in the control group required reintubation, only $30 \%$ of patients in the prospective treatment cohort failed NIV and mechanical cough-assist therapy.

In another prospective study, 3375 patients who passed a spontaneous breathing trial were randomized to receive protocolized care involving NIV either with cough-assist therapy or with usual care during the first $48 \mathrm{~h}$ following extubation. NIV was initiated in either group only when predetermined signs of respiratory distress developed. In the experimental arm of the study, mechanical cough-assist therapy was initiated once prior to extubation, and continued with daily therapy sessions (3 treatments per day) for an additional 8 days. Significantly fewer patients in the mechanical cough-assist group required reintubation, compared to those who received NIV and usual care alone (17\% vs $48 \%$, respectively, $P<.05$ ).

Although these results are encouraging, there are several potential problems that could arise when introducing mechanical cough-assist therapy in a general ICU population. In patients at risk for sudden lung collapse (eg, ARDS, morbid obesity, abdominal compartment syndrome) disconnection from mechanical ventilation along with the application of high negative airway pressure could result in sudden profound hypoxemia. In such patients who also present with copious thick secretions, IPV therapy would appear to be a more reasonable and safer therapeutic option. As pointed out by others, mechanical cough-assist therapy cannot be recommended in non-intubated patients with severe respiratory distress and hypoxemia, or anxiety/ agitation. ${ }^{34}$

\section{Aerosolized Medications}

Probably the most important adjunctive therapy during mechanical ventilation is the delivery of aerosolized pharmacologic agents. Historically, aerosolized drug delivery during invasive mechanical ventilation has been less efficient, compared to spontaneous breathing in the absence of an artificial airway. For example, only $2.9 \%$ of an administered dose via mechanical ventilation has been reported
Table 2. Factors That May Promote Better Pulmonary Aerosol Deposition

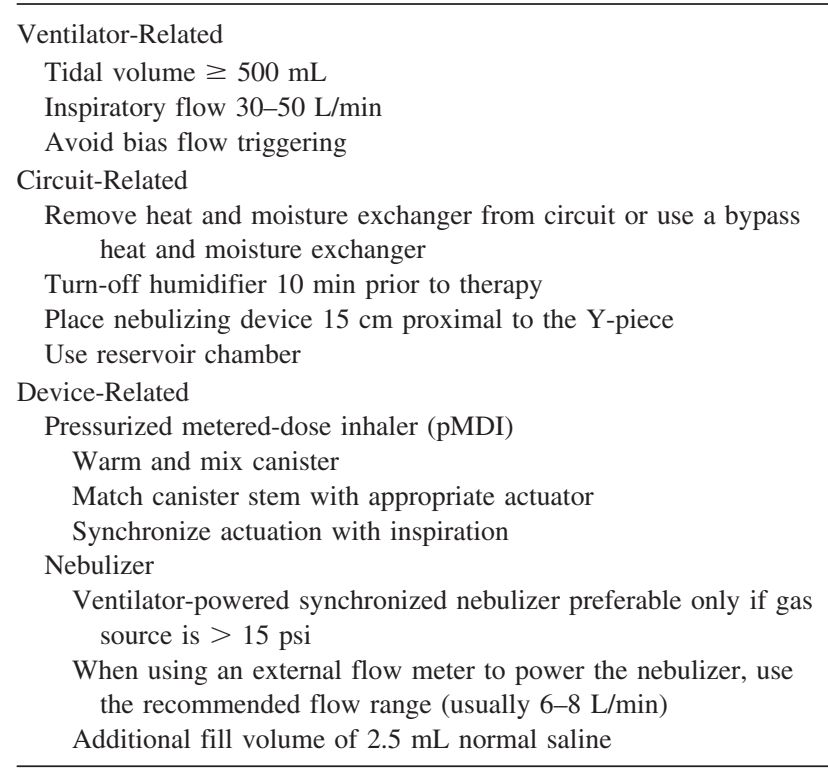

to actually reach the lower respiratory tract, compared to $11.9 \%$ when an artificial airway is not present. ${ }^{35}$ The paramount problem is substantial drug loss from impaction upon the artificial airway, caused by flow resistance. ${ }^{35}$ However, a host of other factors limit efficient aerosolized drug delivery, and these have been classified as ventilatorrelated, circuit-related, and device-related (Table 2). ${ }^{36-41}$ For the purpose of this discussion, both ventilator and circuit-related problems will be discussed within the context of aerosol delivery devices: pressurized metered-dose inhaler (pMDI) and nebulizer.

Traditionally, pMDI therapy has been reported to yield a higher deposition within the lower respiratory tract, compared to nebulizers $(0.3-97.5 \%$ vs $0-42 \%$, respectively), but these findings must be viewed within a historical context of different methodologies and lack of an accepted standardized model for aerosol testing. ${ }^{41}$ Under conditions of standardized testing, similar results have been found between delivery devices (ie, approximately $15 \%$ ). ${ }^{40,41}$ In general, pMDI bronchodilator and corticosteroid therapy has been widely employed during mechanical ventilation, as it is considered to be more economical with less risk for nosocomial pneumonia, compared to nebulized therapy. ${ }^{41}$ However, with the conversion from generic chlorofluorocarbon to brand name hydrofluoroalkane propellants, the economic advantages of using pMDI may diminish. ${ }^{40}$ Furthermore, advances in nebulizer technology have lessened the problems around drug wastage, thus improving both its efficiency and cost. For example, it was recently reported that using newer nebulizer technology to deliver bronchodilators to mechanically ventilated patients may reduce costs by approximately $80 \%$, compared to pMDI based 
therapy. ${ }^{38}$ Below is a review of the advantages and disadvantages of both pMDI and nebulizers, followed by a discussion of various non-bronchodilator, adjunctive aerosol therapies during mechanical ventilation.

\section{Pressurized Metered-Dose Inhalers}

When pMDIs are used, drug delivery is strongly influenced by the choice of pMDI adapter, the position of the adapter within the ventilator circuit, both use and type of reservoir chamber, the timing of pMDI actuation, whether inspired gases are conditioned with heat and humidity, and the type of pMDI used. ${ }^{36,40,41}$ For example, improved bronchodilator effects of $\beta$ agonists occur when a reservoir chamber is placed $15 \mathrm{~cm}$ proximal to the circuit Y-pieceadapter. ${ }^{42}$ More subtle details, such as whether the reservoir chamber is unidirectional or bidirectional, ${ }^{43}$ matching the pMDI canister stem with the actuator, ${ }^{44}$ and simply assuring that the pMDI canister is warmed and shaken (to assure proper mixing of drug and propellant), ${ }^{36}$ also can affect the efficiency of drug delivery during mechanical ventilation.

Actively heating and humidifying inspired gases during mechanical ventilation reduces aerosol deposition by approximately $40 \%,{ }^{41}$ and is believed to be caused by hygroscopic growth of aerosol particles that are filtered out by the artificial airway. Yet turning off or removing active humidification from the ventilator circuit during treatments is not recommended, ${ }^{36}$ as it is both impractical and introduces additional problems. These include allowing sufficient time for the ventilator circuit to cool and dry (thus increasing duration of therapy), frequent circuit disconnections that increase the risk of both lung de-recruitment and inadvertent circuit contamination, and damaging the airway mucosa from repeated exposure to dry gases. This last point is particularly important if humidification inadvertently is not resumed following therapy, as might occur during high work load periods in a busy ICU. Furthermore, reduced aerosol delivery occurs when a heated wire circuit is used, particularly if substantial condensation forms in the spacer and tubing. ${ }^{45}$ Interestingly, shutting off the humidifier for $10 \mathrm{~min}$ prior to therapy appears to have little impact on improving drug delivery. ${ }^{44}$ In contrast, passive humidification with a heat and moisture exchanger creates a formidable barrier to aerosol delivery and must be removed prior to therapy unless a specific bypass device is used.

Another potential barrier to pMDI efficiency is its use during spontaneous modes of ventilation. Asynchrony between pMDI actuation and the onset of inspiratory flow can substantially reduce drug delivery, particularly if actuation occurs during expiration. ${ }^{46}$ This issue becomes important when pMDIs are used during spontaneous modes of ventilation such as pressure support ventilation, as appropriate synchronization is difficult.

The breathing pattern during mechanical ventilation also impacts drug delivery. A sufficiently large tidal volume of approximately $500 \mathrm{~mL}(7-8 \mathrm{~mL} / \mathrm{kg}$ for an average-sized adult), long inspiratory time and slow inspiratory flow $(30-50 \mathrm{~L} / \mathrm{min})$ are required to optimize drug delivery. ${ }^{36,40,41}$ These variables cannot be controlled when spontaneous breathing modes are used, particularly in the presence of tachypnea. Although these factors also are in play when nebulizers are used, the fact that drug delivery is based upon only a very limited number of actuations per treatment (compared to 5-10 min of sustained therapy with a nebulizer) may render the use of pMDI more vulnerable to inefficiency.

\section{Nebulizers}

When nebulizers are used, important considerations include the position of the nebulizer and use of a reservoir chamber, the type of nebulizer used, fill volume, breathing frequency, inspiratory time, inspiratory flow, inspired tidal volume, triggering mechanism (ie, pressure vs bias flow triggering), whether inspired gases are conditioned with heat and humidity as well as type of humidifier used, the gas flow used to power nebulization, and whether nebulization occurs continuously throughout the respiratory cycle or is synchronized with inspiration. ${ }^{36,40,41}$

There are 3 distinct types of nebulizer commonly used (ie, jet, ultrasonic, and vibrating mesh or plate), each with unique features. Therefore, considering the pros and cons of nebulizer choice becomes more complicated. However, some of the same adjustments and limitations described for pMDIs apply equally for all nebulizers. For example, proximal placement of a nebulizer in relation to the circuit Y-piece-adapter, ${ }^{47}$ along with incorporation of an aerosol reservoir, ${ }^{48}$ increases drug delivery to the patient. Heated, humidified gases also have a negative impact, accounting for substantial reductions in drug delivery. ${ }^{49}$

In particular, when jet nebulizers are used, consideration must be given to the fact that aerosol production and particle size may vary not only between brands but also between different batches within the same brand. ${ }^{50}$ The gas flow source used to power a jet nebulizer introduces another level of complexity. Using a high-pressure external flow meter to power the jet nebulizer can produce a higher proportion of aerosol particles capable of deposition within the lower respiratory tract (ie, mass median aerodynamic diameter of 1-3 $\mu \mathrm{m})$. However, each model of jet nebulizer is designed to work at a specific flow range, which is usually stated by the manufacturer. Typically this is $6-8 \mathrm{~L} / \mathrm{min} \cdot{ }^{36,39,41,47}$ Powering a jet nebulizer at a flow rate below its recommended range renders the device less efficient, causing increased drug retention within 
the nebulizer and producing larger, more heterodispersed particles that tend to be filtered out by the artificial airway. ${ }^{47}$

A jet nebulizer powered by an external flow meter produces aerosol throughout the ventilatory cycle, thus increasing drug wastage. Likewise, the use of bias flow triggering, particularly at flows $>2 \mathrm{~L} / \mathrm{min}$, will increase drug wastage. ${ }^{36}$ Synchronized, intermittent nebulization using the internal nebulizer function on ventilators reduces drug wastage. ${ }^{49,51}$ Historically, this technique was commonly avoided because on many older ventilators the intermittent nebulization feature was substantially under-powered (eg, $15 \mathrm{psi}) .{ }^{52}$ This resulted in excessive treatment duration and insufficient gas flow to generate respirable particle sizes. Also there is a tendency for preferential aerosolization of normal saline diluent with jet nebulizers that results in a residual or "dead volume" of $0.1-2.4 \mathrm{~mL}$ containing a higher drug concentration. ${ }^{36}$ Because jet nebulizers do not function below the dead volume, less drug is delivered to the patient. Increasing the fill volume lessens the amount of drug retained within the nebulizer. ${ }^{36,41,47}$

An ultrasonic nebulizer produces aerosol through vibration of a piezo-electric crystal. Its performance is related to the frequency and amplitude capabilities, so that the efficiency of any nebulizer may vary between manufacturers. ${ }^{41}$ An advantage of ultrasonic nebulizers is their higher rate of aerosol output and shorter duration of therapy. ${ }^{53,54}$ Although better deposition, compared to jet nebulizer, has been reported with newer models, ${ }^{53}$ the impression is that the ultrasonic nebulizer technology requires more development in order to achieve wider acceptance. ${ }^{55}$ For example, the versatility of ultrasonic nebulizers in clinical practice may be restricted due to heating issues. In contrast to jet nebulizers (in which drug solutions cool during aerosolization), ultrasonic nebulizers tend to heat up solutions as much as $20^{\circ} \mathrm{C}$ over 6 min. ${ }^{56}$ This could denature some drug preparations, rendering them ineffective. And it already appears that ultrasonic technology has been supplanted by newer technologies. ${ }^{40}$

The newest nebulization technique for clinical practice uses a vibrating mesh or plate to generate an aerosol output 2 to 3 times greater than jet nebulizer, with a nominal antibiotic dose delivery of $60 \%$, with virtually no residual volume. ${ }^{40} \mathrm{~A} 2$ to 4 fold higher albuterol delivery also has been reported with a vibrating mesh nebulizer, compared to jet nebulization, during mechanical ventilation. ${ }^{57} \mathrm{An}$ other advantage of a vibrating mesh nebulizer is that it can aerosolize proteins and peptides without risk of denaturation and therefore opens more opportunities for inhaled pharmacotherapies. ${ }^{40}$

In summary, several practical steps can be taken to improve aerosolized medication delivery to the lungs with both pMDI and nebulizer delivery systems. Although pMDI has long been considered the more efficient and economic delivery method, improvements in nebulizer technology and the recent changeover to brand name hydrofluoroalkane propellants may diminish, if not remove, that rationale. In particular, the advent of vibrating mesh nebulizer technology appears to be better suited for delivering an increasingly diverse array of drugs.

\section{Aerosolized Antibiotics}

The reported incidence of VAP is $8-28 \%,,^{58}$ and VAP is the most frequent hospital-acquired infection among surgical ICU patients. ${ }^{59}$ VAP is the leading cause of death among critically ill patients with hospital-acquired infection, and has an associated mortality between $25-50 \%$ (as high as $76 \%$ in some circumstances). ${ }^{58}$ Also, it accounts for more than $50 \%$ of antibiotic use in the ICU. ${ }^{60}$ In particular, VAP caused by Pseudomonas aeruginosa is very difficult to treat, as it is characterized by both recurrent infection and a high tendency toward antibiotic resistance, despite appropriate antibiotic management. ${ }^{61}$

Moreover, systemic antibiotics may not be ideal for treating pneumonia. Achieving an appropriately high concentration capable of eradicating bacterial reservoirs residing within thick secretions and biofilm is difficult. It requires drug dosages that may increase the likelihood of systemic toxicity, ${ }^{62}$ as well as eliminate the normal flora of the gastrointestinal tract. This, in consequence, paradoxically promotes the selection of multi-drug resistant (MDR) organisms. ${ }^{63}$ In our current situation, marked by an increasing prevalence of MDR pathogens, and coinciding with a shrinking array of effective antibiotics, there is renewed interest in using aerosolized antibiotics to treat both VAP and ventilator-associated tracheobronchitis (VAT). VAT is considered a precursor to VAP, and both conditions share similar microbiologic and features of presentation. ${ }^{64}$ However, the most salient distinctions are that while VAT also presents after $48 \mathrm{~h}$ of mechanical ventilation with both fever and leukocytosis (or leukopenia), worsening oxygenation and chest radiographic findings of a new, persistent or worsening infiltrate may be absent.

For several decades aerosolized antibiotics have been used successfully to treat both cystic fibrosis and Pneumocystis jiroveci pneumonia. ${ }^{65}$ In particular, the efficiency of vibrating mesh nebulizer technology may be an important step in advancing aerosolized antibiotic therapy. ${ }^{57} \mathrm{Sev}-$ eral small RCTs, as well as uncontrolled studies, ${ }^{66-77}$ have been published (Table 3). Although not uniformly unambiguous, many of these studies suggest that aerosolized antibiotics maybe a more effective strategy to treat VAP and VAT.

Since 2000 there have been 6 small prospective RCTs that have examined aerosolized antibiotics for the treatment ${ }^{67,72,74,77}$ or prevention of VAP. ${ }^{75,76}$ Of the treatment trials, those done by Palmer et $\mathrm{al}^{67}$ and $\mathrm{Lu}$ et al ${ }^{72}$ merit 


\section{Adjunct Therapies During Mechanical Ventilation}

Table 3. Contemporary Studies of Aerosolized Antibiotics for the Treatment or Prevention of ventilator-Associated Pneumonia

\begin{tabular}{|c|c|c|c|c|c|c|}
\hline First Author & Year & Study Type & $\begin{array}{l}\text { Level of } \\
\text { Evidence }\end{array}$ & $n$ & Setting/Protocol & Trial Results \\
\hline Palmer $^{67}$ & 2008 & $\begin{array}{l}\text { Double-blind } \\
\text { RCT }\end{array}$ & II & 43 & $\begin{array}{l}\text { General ICU population } \\
\text { Late-onset VAP/ventilator-associated } \\
\text { tracheobronchitis } \\
\text { Microbiologically confirmed via Gram } \\
\text { stain } \\
\text { Normal saline vs aerosolized AB: } \\
\quad \text { vancomycin }(120 \mathrm{mg} \text { every } 8 \mathrm{~h}) \text { or } \\
\text { gentamicin }(80 \mathrm{mg} \text { every } 8 \mathrm{~h} \text { ) for } \\
14 \mathrm{~d} \text {, based on sputum collected via } \\
\text { tracheal suctioning and Gram stain } \\
\text { Aerosolized AB via jet nebulizer: high } \\
\text { quality delivery technique } \\
\text { Additional intravenous AB }\end{array}$ & $\begin{array}{l}\text { Benefit } \\
\text { Significant } \downarrow \text { in signs of infection, } \\
\text { white blood cell count, and need } \\
\text { for intravenous AB } \\
33 \% \text { of control group developed } \\
\text { acquired resistance, vs } 0 \% \text { in } \\
\text { aerosolized AB group } \\
\uparrow \text { ventilator-free days in first } 28 \mathrm{~d} \\
\text { No difference in } 28 \text {-d mortality }\end{array}$ \\
\hline $\mathrm{Lu}^{72}$ & 2011 & $\begin{array}{l}\text { Unblinded } \\
\text { RCT }\end{array}$ & II & 40 & $\begin{array}{l}\text { Primarily trauma/surgical ICU patients } \\
\text { VAP onset not specified } \\
\text { Microbiologically confirmed VAP } \\
\text { caused by Pseudomonas aeruginosa: } \\
\text { primarily susceptible and } \\
\text { intermediate species } \\
\text { Aerosolized AB: ceftazidime } 15 \mathrm{mg} / \mathrm{kg} \\
\times 8 \mathrm{doses} / \mathrm{d} \times 8 \mathrm{~d}+\text { amikacin } \\
(25 \mathrm{mg} / \mathrm{kg} \times 1 \text { dose } / \mathrm{d} \times 3 \mathrm{~d}) \\
\text { Aerosolized } \mathrm{AB} \text { via vibrating plate } \\
\text { nebulizer: high quality delivery } \\
\text { technique } \\
\text { Intravenous } \mathrm{AB} \text { group: daily doses of } \\
\text { ceftazidime }(90 \mathrm{mg} / \mathrm{kg})+\text { amikacin } \\
(15 \mathrm{mg} / \mathrm{kg})\end{array}$ & $\begin{array}{l}\text { Uncertain benefit } \\
\text { Similar results with favorable trends } \\
\text { supporting larger RCT of } \\
\text { aerosolized AB vs intravenous } \\
\text { AB } \\
\text { Day } 9 \text { "cure rate": } 70 \% \text { vs } 55 \% \\
\text { Treatment failure: } 15 \% \text { vs } 30 \% \\
\text { More rapid eradication of pathogens } \\
\text { with aerosolized AB } \\
\text { No direct adverse events (eg, } \\
\text { bronchospasm) with aerosolized } \\
\text { AB, but } 3 \text { incidents of expiratory } \\
\text { limb circuit occlusion }\end{array}$ \\
\hline Wood $^{75}$ & 2002 & $\begin{array}{l}\text { Double-blind } \\
\text { RCT }\end{array}$ & II & 40 & $\begin{array}{l}\text { Prophylaxis for VAP in a trauma ICU } \\
\text { Aerosolized } \mathrm{AB} \text { : ceftazidime }(250 \mathrm{mg} \\
\text { every } 12 \mathrm{~h} \times 7 \mathrm{~d}) \text { vs normal saline } \\
\text { Aerosolized } \mathrm{AB} \text { via jet nebulizer: high } \\
\text { quality delivery technique } \\
\text { Outcomes: incidence of VAP and } \\
\text { inflammatory mediators in BAL }\end{array}$ & $\begin{array}{l}\text { Benefit } \\
\text { Lower incidence of VAP, compared } \\
\text { to placebo at day } 14 \text { (15\% vs } \\
55 \%) \text { and throughout ICU stay } \\
(30 \% \text { vs } 65 \%) \\
\text { Less pro-inflammatory mediator } \\
\text { release, compared to placebo } \\
\text { Significant relationship between } \\
\text { incidence of VAP and pro- } \\
\text { inflammatory mediator release }\end{array}$ \\
\hline Claridge $^{76}$ & 2007 & $\begin{array}{l}\text { Double-blind } \\
\text { RCT }\end{array}$ & II & 105 & $\begin{array}{l}\text { Prophylaxis for VAP } \\
\text { Trauma ICU } \\
\text { Aerosolized AB: ceftazidime ( } 250 \mathrm{mg} \\
\quad \text { every } 12 \mathrm{~h} \times 7 \mathrm{~d}) \text { vs normal saline } \\
\text { Aerosolized AB via jet nebulizer: high } \\
\quad \text { quality delivery technique } \\
\text { Outcome: incidence of VAP }\end{array}$ & $\begin{array}{l}\text { No benefit } \\
\text { No difference in incidence of VAP } \\
\text { between aerosolized AB group } \\
\text { and placebo group either at } \\
\text { day } 14(40 \% \text { vs } 46 \%) \text { or day } 30 \\
\text { ( } 49 \% \text { vs } 50 \%) \\
\text { Incidence of MDR isolates not } \\
\text { different }\end{array}$ \\
\hline Hallal $^{77}$ & 2007 & $\begin{array}{l}\text { Double-blind } \\
\text { RCT }\end{array}$ & II & 10 & $\begin{array}{l}\text { Surgical/trauma ICU } \\
\text { VAP onset not specified } \\
\text { Microbiologically confirmed VAP } \\
\text { caused by Pseudomonas aeruginosa } \\
\text { or Acinetobacter baumannii } \\
\text { Aerosolized tobramycin ( } 300 \text { mg every } \\
12 \mathrm{~h} \text { ) vs normal saline } \\
\text { Additional intravenous AB } \\
\text { Aerosolized AB via jet nebulizer: high } \\
\text { quality delivery technique }\end{array}$ & $\begin{array}{l}\text { Uncertain benefit } \\
\text { Clinical "cure" in } 100 \% \text { of } \\
\text { aerosolized AB group vs } 60 \% \text { of } \\
\text { intravenous AB group } \\
\text { Trend towards } \uparrow \text { ventilator-free } \\
\text { days in aerosolized AB group, } \\
\text { but the } 2 \text { "failure" cases in the } \\
\text { intravenous AB group appeared } \\
\text { to have more severe illness } \\
\text { No adverse events associated with } \\
\text { aerosolized AB }\end{array}$ \\
\hline
\end{tabular}


Table 3. Continued

\begin{tabular}{|c|c|c|c|c|c|c|}
\hline First Author & Year & Study Type & $\begin{array}{l}\text { Level of } \\
\text { Evidence }\end{array}$ & $n$ & Setting/Protocol & Trial Results \\
\hline LeConte $^{74}$ & 2000 & $\begin{array}{l}\text { Double-blind } \\
\text { RCT }\end{array}$ & II & 38 & $\begin{array}{l}\text { Article in French: brief abstract in } \\
\text { English } \\
\text { Aerosolized } \mathrm{AB} \text { : tobramycin }(6 \mathrm{mg} / \mathrm{kg} / \\
\mathrm{d} \times 5 \mathrm{~d}) \\
\text { Aerosolized } \mathrm{AB} \text { via jet nebulizer: } \\
\text { vague description of delivery } \\
\text { technique, unable to assess quality }\end{array}$ & $\begin{array}{l}\text { Uncertain benefit } \\
\text { Analysis at day } 10 \text { : trend toward } \\
\text { higher weaning success in } \\
\text { aerosolized } \mathrm{AB} \text { vs placebo group } \\
(35 \% \text { vs } 18.5 \%, P=.18) \\
\text { No adverse events associated with } \\
\text { aerosolized } \mathrm{AB}\end{array}$ \\
\hline Michalopoulos $^{68}$ & 2008 & $\begin{array}{l}\text { Prospective } \\
\text { uncontrolled, } \\
\text { no } \\
\text { comparison } \\
\text { group }\end{array}$ & IV & 60 & $\begin{array}{l}\text { General ICU population } \\
\text { Late-onset VAP } \\
\text { Study delimitation: VAP from MDR } \\
\text { Gram-negative bacilli, but sensitive } \\
\text { to colistin } \\
\text { VAP confirmed via sputum culture } \\
\text { (BAL or sputum collected via } \\
\text { tracheal suctioning) } \\
\text { Treatment: aerosolized AB of } 1 \text { million } \\
\text { international units colistin } 3 \text { times a } \\
\text { day and intravenous AB with } \\
\text { colistin/meropenem } \\
\text { AB delivery technique: vague } \\
\text { description, unable to assess quality }\end{array}$ & $\begin{array}{l}\text { Benefit } \\
83 \% \text { of patients had improvement } \\
\text { in arterial blood gases and } \\
\text { normalization in white blood cell, } \\
\text { C-reactive protein, and } \\
\text { procalcitonin levels } \\
\text { No adverse events associated with } \\
\text { aerosolized AB }\end{array}$ \\
\hline Czosnowski $^{70}$ & 2009 & $\begin{array}{l}\text { Retrospective, } \\
\text { uncontrolled, } \\
\text { no } \\
\text { comparison } \\
\text { group }\end{array}$ & IV & 49 & $\begin{array}{l}\text { Level-1 trauma ICU } \\
\text { Late-onset VAP } \\
\text { Microbiologically confirmed VAP } \\
\text { caused by Pseudomonas aeruginosa } \\
\text { or Acinetobacter baumannii } \\
60 \text { episodes of VAP with aerosolized } \\
\text { AB: tobramycin } 300 \text { mg every } 12 \mathrm{~h} \\
\text { (44), amikacin } 1 \text { g every } 12 \mathrm{~h}(9) ; \\
\text { colistin } 150 \mathrm{mg} \text { every } 12 \mathrm{~h}(9) \\
\text { Aerosolized AB via jet nebulizer: high } \\
\text { quality delivery technique }\end{array}$ & $\begin{array}{l}\text { Benefit } \\
\text { "Clinical success" of } 73 \% \text { for both } \\
\text { initial and subsequent episodes } \\
\text { Microbiological success (by follow- } \\
\text { up BAL) } 69 \% \text {, failure } 26 \% \text {, } \\
\text { inconclusive } 5 \%\end{array}$ \\
\hline $\operatorname{Lin}^{71}$ & 2010 & $\begin{array}{l}\text { Retrospective, } \\
\text { uncontrolled, } \\
\text { no } \\
\text { comparison } \\
\text { group }\end{array}$ & IV & 45 & $\begin{array}{l}\text { General ICU population } \\
\text { VAP onset not specified } \\
\text { Microbiologically confirmed VAP } \\
\text { caused by MDR Acinetobacter } \\
\text { baumannii } \\
\text { Aerosolized AB: colistin ( } 4.3 \text { million } \\
\text { international units/d [divided into } 3 \\
\text { doses] } \times 10 \mathrm{~d}) \\
\text { Aerosolized AB delivery technique: } \\
\text { vague description, unable to assess } \\
\text { quality } \\
\text { Additional intravenous AB }\end{array}$ & $\begin{array}{l}\text { Uncertain Benefit } \\
58 \% \text { had positive clinical outcomes } \\
\text { ("cured" or "improved") vs } 31 \% \\
\text { treatment failure } \\
\text { Microbiologic outcomes: } 38 \% \\
\text { pathogen eradication vs } 18 \% \\
\text { with persistent infection } \\
40 \% \text { did not have microbiologic } \\
\text { follow-up after aerosolized AB } \\
\text { No adverse events associated with } \\
\text { aerosolized AB }\end{array}$ \\
\hline
\end{tabular}

further discussion. Palmer et $\mathrm{al}^{67}$ studied 43 patients with VAT, randomized to receive either aerosolized normal saline or aerosolized antibiotics, based upon the Gram stain of sputum (ie, $120 \mathrm{mg}$ vancomycin every $8 \mathrm{~h}$ for Grampositive bacterial infections, or $80 \mathrm{mg}$ gentamicin every $8 \mathrm{~h}$ for Gram-negative bacterial infection) in addition to intravenous antibiotic therapy. Those treated with aerosolized antibiotics had a significant reduction in signs of respiratory infection, white blood cell count, bacterial resis- tance, and use of intravenous antibiotics, compared to the control group. Fewer patients in the treatment group required additional antibiotics, either for new or persistent infection, compared to the control group (42\% vs $71 \%$, respectively). Although 28-day mortality was not different between the groups, among survivors $80 \%$ of those receiving aerosolized antibiotics were successfully weaned during the study, compared to $45 \%$ in the control group $(P=.046)$. Also there was a strong tendency toward higher 
Table 3. Continued

\begin{tabular}{|c|c|c|c|c|c|c|}
\hline First Author & Year & Study Type & $\begin{array}{l}\text { Level of } \\
\text { Evidence }\end{array}$ & $n$ & Setting/Protocol & Trial Results \\
\hline Mohr $^{66}$ & 2007 & $\begin{array}{l}\text { Retrospective, } \\
\text { uncontrolled, } \\
\text { no } \\
\text { comparison } \\
\text { group }\end{array}$ & IV & 22 & $\begin{array}{l}\text { Surgical/trauma ICU } \\
\text { Late-onset VAP } \\
\text { Microbiologically confirmed VAP via } \\
\text { BAL ( } 86 \% \text { ) caused primarily by } \\
\text { Pseudomonas aeruginosa ( } 86 \% \text {, and } \\
\text { also Acinetobacter baumannii, } \\
\text { Escherichia coli, and Klebsiella } \\
\text { pneumoniae } \\
\text { MDR found in } 36 \% \text { of isolates } \\
\text { Aerosolized AB: tobramycin ( } 300 \mathrm{mg} \\
\text { every } 12 \mathrm{~h} \times 7 \mathrm{~d} \text { ) or amikacin } \\
\text { ( } 400 \text { mg every } 8 \text { or } 12 \mathrm{~h} \times 7 \mathrm{~d}) \\
\text { Aerosolized AB delivery technique: } \\
\text { vague description, unable to assess } \\
\text { quality } \\
\text { Additional intravenous AB }\end{array}$ & $\begin{array}{l}\text { Uncertain benefit } \\
45 \% \text { had positive clinical and } \\
\text { microbiologic outcomes } \\
41 \% \text { recurrent pneumonia after } \\
\text { treatment } \\
14 \% \text { recurrent pneumonia with new } \\
\text { MDR strain }\end{array}$ \\
\hline Ghannam $^{69}$ & 2009 & $\begin{array}{l}\text { Retrospective, } \\
\text { uncontrolled, } \\
\text { with } \\
\text { comparison } \\
\text { group }\end{array}$ & III & 32 & $\begin{array}{l}\text { Oncology ICU } \\
\text { VAP onset not specified } \\
\text { Microbiologically confirmed VAP not } \\
\text { explicitly stated, but primary pathogen } \\
\text { was Pseudomonas aeruginosa ( } 69 \%) \text {, } \\
\text { and also Klebsiella pneumonia, } \\
\text { Stenotrophomonas maltophilia, and } \\
\text { Serratia marcescens } \\
\text { Aerosolized AB: tobramycin ( } 300 \mathrm{mg} \\
\text { twice a day), amikacin ( } 100 \mathrm{mg} \\
3 \text { times a day), gentamicin (100 mg } \\
3 \text { times a day), colistin (100 mg } \\
\text { every } 8 \text { h) } \\
\text { Aerosolized AB delivery via jet } \\
\text { nebulizer: no specific information on } \\
\text { technique } \\
\text { Additional intravenous AB } \\
\text { Case-matched control patients received } \\
\text { comparable intravenous AB ( } n=16 \\
\text { in each group) }\end{array}$ & $\begin{array}{l}\text { Benefit } \\
\text { Complete clinical resolution: } \\
\text { aerosolized } \mathrm{AB}(100 \%), \\
\text { intravenous } \mathrm{AB}(55 \%) \\
\text { Microbiologic eradication: } \\
\text { aerosolized } \mathrm{AB}(77 \%), \\
\text { intravenous } \mathrm{AB}(8 \%) \\
\text { No adverse events associated with } \\
\text { aerosolized } \mathrm{AB}\end{array}$ \\
\hline Arnold $^{73}$ & 2012 & $\begin{array}{l}\text { Retrospective, } \\
\text { uncontrolled, } \\
\text { with } \\
\text { comparison } \\
\text { group }\end{array}$ & III & 93 & $\begin{array}{l}\text { General ICU population } \\
\text { Late-onset VAP } \\
\text { VAP microbiologically confirmed via } \\
\text { BAL, caused by Pseudomonas } \\
\text { aeruginosa or Acinetobacter } \\
\text { baumannii } \\
\text { Aerosolized AB }(n=19) \text { : tobramycin } \\
\quad(300 \mathrm{mg} \text { twice a day } \times 11 \mathrm{~d}) \text {, colistin } \\
\quad(150 \mathrm{mg} \text { twice a day } \times 9 \mathrm{~d}) \\
\text { Aerosolized AB via jet nebulizer: high } \\
\text { quality delivery technique } \\
\text { Additional intravenous AB } \\
\text { Comparison group }(n=74) \text { : } \\
\text { intravenous AB only }\end{array}$ & $\begin{array}{l}\text { Benefit } \\
\text { Intravenous AB group had } \\
\text { significantly } \downarrow \text { duration of } \\
\text { mechanical ventilation and } \\
\downarrow \text { ICU/hospital stay } \\
\text { Greater severity of illness and } \\
\text { MDR infection among } \\
\text { aerosolized AB group } \\
\text { 30-d survival in aerosolized AB } \\
\text { group } \\
\text { Recurrent VAP after treatment was } \\
\text { similar between groups } \\
\text { No adverse events associated with } \\
\text { aerosolized AB }\end{array}$ \\
\hline \multicolumn{7}{|c|}{$\begin{array}{l}\mathrm{RCT}=\text { randomized controlled trial } \\
\mathrm{VAP}=\text { ventilator-associated pneumonia } \\
\mathrm{AB}=\text { antibiotic } \\
\mathrm{MDR}=\text { multidrug resistant } \\
\mathrm{BAL}=\text { bronchoalveolar lavage }\end{array}$} \\
\hline
\end{tabular}


ventilator-free days among those in the treatment group, compared to the control group, (median of 10 vs 0 , respectively, $P=.07$ ).

Recently, the Nebulized Antibiotics Study Group ${ }^{72}$ published the results of a phase II RCT comparing an 8-day course of aerosolized versus intravenous administration of both ceftazidime and amikacin in 40 patients with confirmed VAP caused by Pseudomonas aeruginosa. By carefully measuring the amount of drug sequestered in the nebulizer and ventilator circuit, it was estimated that approximately $63 \%$ of the nebulized dose was delivered to the respiratory tract. Compared to intravenous therapy, those patients receiving aerosolized antibiotics had a tendency toward higher resolution of VAP (55\% vs $70 \%$, $P=.33$, respectively) and less treatment failure (30\% vs $15 \%$, respectively), as well as more rapid reduction in bacterial growth. The investigators did report a small number of important adverse events with aerosolized antibiotics, including a $25 \%$ decrease in $\mathrm{P}_{\mathrm{aO}_{2}} / \mathrm{F}_{\mathrm{IO}_{2}}$ after treatment in 3 patients $(15 \%)$ and expiratory limb circuit filter obstruction in another 3 patients, one of whom suffered a cardiac arrest.

There have been 2 recent prophylaxis studies ${ }^{75,76}$ of aerosolized antibiotics in trauma patients. Critically ill patients with traumatic injuries seemingly are more susceptible to developing VAP than the general ICU population, and this tends to be associated with increased morbidity and mortality. ${ }^{78}$ In a preliminary safety/efficacy study, Wood et $\mathrm{al}^{75}$ found an impressive $73 \%$ reduction in the incidence of VAP among trauma patients treated for one week with aerosolized ceftazidime, compared to placebo. For the entire ICU stay the incidence of VAP was 54\% lower. These positive results were associated with significant reductions in alveolar concentrations of pro-inflammatory mediators (eg, tumor necrosis factor alpha and interleukin 1-beta). In addition, the investigators delimited the study to those patients at high risk for VAP and restricted treatment exposure so as to reduce the chances of promoting the selection of MDR microorganisms. As a result, the bacterial flora and sensitivity patterns were not altered.

Unfortunately, in a larger follow-up study ${ }^{76}$ the same investigators were unable to duplicate their results, as the incidence of VAP (both at 2 weeks and $30 \mathrm{~d}$ ) was the same. However, it was noteworthy that the number of patients who developed infections with MDR microorganisms was not different, thus supporting previous observations that brief courses of aerosolized antibiotics do not appear to alter the microbiologic ecology in the ICU setting.

Several retrospective studies also merit discussion. Among these, Michalopoulos et al ${ }^{68}$ reported on 60 patients who were treated prospectively with aerosolized colistin as an adjunct to intravenous antibiotic therapy for
VAP. Fifty (83\%) patients showed a positive response to therapy (eg, improved chest radiograph and arterial blood gases, normalization of white blood cell count, C-reactive protein, and procalcitonin levels) without adverse effects. Likewise, Mohr et al ${ }^{66}$ reported significant improvement in oxygenation $\left(\mathrm{P}_{\mathrm{aO}_{2}} / \mathrm{F}_{\mathrm{IO}_{2}}\right.$ increased from $201 \pm 92 \mathrm{~mm} \mathrm{Hg}$ to $250 \pm 90 \mathrm{~mm} \mathrm{Hg}, P<.05$ ), and no adverse pulmonary effects or renal toxicity from aerosolized tobramycin or amikacin among 22 patients with VAP. In terms of efficacy in treating infection, the results were mixed. Whereas $45 \%$ of patients had resolution of VAP and complete eradication of the responsible pathogen, pneumonia recurred in $41 \%$, but in only one case did the responsible microorganism become newly MDR.

Ghannam et al ${ }^{69}$ also reported no adverse effects from either aerosolized tobramycin or colistin in a retrospective case-control study. Therapeutic efficacy in this study was impressive, as all patients treated with aerosolized antibiotics had complete resolution of pneumonia, compared to $55 \%$ of those receiving intravenous antibiotic therapy alone $(P<.01)$. Also, among patients who had follow-up lower respiratory tract cultures, bacterial eradication was complete in $77 \%$ of patients who received aerosolized antibiotic therapy, compared to $8 \%$ among those receiving intravenous antibiotic therapy alone $(P<.001)$. Most recently, in a retrospective study of patients with VAP, despite greater illness severity and infection with MDR strains of Pseudomonas aeruginosa or Acinetobacter baumannii, those who received either aerosolized tobramycin or colistin had significantly greater 30-day survival, compared to those who received intravenous antibiotic therapy alone. ${ }^{73}$

Despite these encouraging results from both prospective and retroprospective studies, aerosolized antibiotics cannot yet be recommended for general practice for several reasons. First is the need to determine clinical efficacy in a sufficiently sized multicenter phase III RCT. There are other concerns that suggest caution before advocating widespread use of aerosolized antibiotics. One is the non-uniform criteria that have been used to judge positive outcomes, such as whether improvement in clinical signs of infection is sufficient for defining efficacy (clinical resolution of infection), or whether the more arduous task of microbiological confirmation of pathogen eradication is necessary. ${ }^{59}$

Another is that 2 preliminary prophylaxis studies ${ }^{79,80}$ done in the 1970s showed a disturbing trend toward rapid selection for MDR as well as atypical microorganisms. In one study, ${ }^{79}$ selection of MDR microorganisms may have been related to the use of aerosolized antibiotics in lowrisk patients who were not mechanically ventilated (ie, where antibiotic aerosol freely escaped into the environment). In the other study, ${ }^{80}$ acquired pneumonia was caused either by MDR or atypical pathogens and was associated 
with a higher than expected mortality rate (64\%). The recent study by Claridge et $\mathrm{al}^{76}$ found that prophylactic treatment is not effective, thus suggesting the risk/benefit ratio of prophylactic, aerosolized antibiotic therapy is untenable. Again, it must be emphasized that the indiscriminant dispersion of antibiotic aerosol into the hospital environment during prolonged therapy (as might occur in non-intubated patients with traditional aerosol delivery systems) increases the likelihood that MDR and atypical microorganisms may emerge. However, restricting aerosolized antibiotic therapy to only intubated, mechanically ventilated patients, wherein antibiotic aerosol can be captured in the ventilator circuit, may greatly reduce this risk factor.

Given the unrelenting evolutionary pressure from emerging MDR microorganisms, a large, multicentered, doubleblinded, RCT of aerosolized antibiotics for the treatment of VAP/VAT is of paramount importance to critical care practice. In the interim, however, it is reasonable to consider using aerosolized antibiotics in highly circumspect, individual cases of VAP; in particular, those cases caused by MDR microorganisms unresponsive to traditional intravenous antibiotic therapy, ${ }^{59}$ or when avoiding renal toxicity is of paramount importance.

\section{Aerosolized Prostaglandins and Inhaled Nitric Oxide}

Since the 1990s there has been interest in managing severe hypoxemia in ARDS with direct pulmonary delivery of vasodilators such as inhaled nitric oxide (INO), ${ }^{81}$ aerosolized prostacyclin $\left(\mathrm{PGI}_{2}\right),{ }^{82}$ and, more recently, alprostadil $\left(\mathrm{PGE}_{1}\right){ }^{83}$ Because these inhaled drugs are distributed preferentially to ventilated areas of the lung, they cause selective pulmonary vasodilation and decrease hypoxemia by increasing ventilation/perfusion matching while avoiding the risk of systemic vasodilation. ${ }^{82} \mathrm{Al}-$ though these therapies do not reverse the primary mechanism for hypoxemia (ie, alveolar flooding and collapse), they provide an alternative approach to supporting pulmonary gas exchange without increasing PEEP or $\mathrm{F}_{\mathrm{IO}_{2}}$. In patients with severe hypoxemia and hemodynamic instability, or in those with limited recruitable lung tissue, inhaled vasodilator therapy is attractive because it provides clinicians with more management flexibility. In addition, $\mathrm{INO}^{81}$ and aerosolized $\mathrm{PGI}_{2}{ }^{84,85}$ reduce pulmonary vascular resistance and pulmonary arterial pressure. Furthermore, inhaled $\mathrm{PGI}_{2}$ has anti-inflammatory properties and inhibits platelet aggregation, which, in theory, may help ameliorate the progression of lung injury. ${ }^{86}$

Several RCTs have consistently shown modest to moderate short-term improvement in oxygenation in patients with ARDS treated with INO. ${ }^{87-90}$ The level of evidence supporting aerosolized $\mathrm{PGI}_{2}$ therapy in ARDS is much weaker, usually consisting of small uncontrolled studies ${ }^{85,91}$ and case reports ${ }^{92-94}$ describing modest to moderate improvements in oxygenation. However, this has not been found consistently among all investigations. ${ }^{83,95}$

It is important to stress that there is no evidence that inhaled vasodilator therapy improves outcomes in ARDS, and it may carry some risks for toxicity. Utilizing either INO or aerosolized $\mathrm{PGI}_{2}$ to treat refractory hypoxemia constitutes "off-label" use and is justified as a rescue therapy in cases of severe ARDS. ${ }^{86}$ High doses of INO can cause methemoglobinemia, and may cause renal dysfunction as well as direct pulmonary toxicity from the enhanced production of free nitrogen radicals that occur in a high $\mathrm{F}_{\mathrm{IO}_{2}}$ environment. ${ }^{96}$ However, these risks do not appear appreciable at currently recommended dose ranges of 5-20 ppm. ${ }^{86}$ Prolonged exposure to inhaled $\mathrm{PGI}_{2}$ has not been thoroughly studied in terms of toxicity. Nonetheless, short-term exposure at moderate doses (eg, $30 \mathrm{ng} / \mathrm{kg} / \mathrm{min}$ ) does not appear to produce pulmonary toxicity. ${ }^{96}$ Early, mild airway irritation has been reported in an animal model exposed to doses greatly exceeding the maximally recommended clinical dose of $50 \mathrm{ng} / \mathrm{kg} / \mathrm{min} .{ }^{97,98}$

In summary the use of both INO and aerosolized $\mathrm{PGI}_{2}$ therapy during mechanical ventilation should be restricted either to support pulmonary gas exchange in very severe cases of ARDS, or in the treatment of severe pulmonary hypertension. Currently, the evidence supporting improved oxygenation is stronger for INO than for aerosolized $\mathrm{PGI}_{2}$. Notwithstanding this imbalance of evidence, the higher costs associated with INO alone are justification for considering aerosolized $\mathrm{PGI}_{2}$ as an alternative. Moreover, it should be stressed that both therapies are strictly supportive and have not been shown to improve outcomes. These therapies may allow stabilization of gas exchange so that definitive therapies have a chance for success.

\section{Aerosolized Anticoagulants and Oxygen Radical Scavengers}

ARDS induced by smoke inhalation injury is strongly associated with mortality in patients with thermal injuries. ${ }^{99}$ Approximately $70 \%$ of patients with smoke inhalation injury develop acute respiratory failure, ${ }^{100}$ and this is a leading cause of death in burn victims. ${ }^{101,102}$ The major pathologic features of inhalational injury include fibrin deposition, cellular debris from epithelial sloughing, and increased mucus production leading to the development of airway casts and severe airway obstruction. In addition, the release of toxic radical oxygen species as a result of complement activation enhances endothelial injury and aggravates pulmonary edema. A combination of aerosolized heparin and $\mathrm{N}$-acetylcysteine has been used in the management of inhalation injuries. ${ }^{103-105}$

Animal models of acute smoke inhalation lung injury have produced somewhat mixed results. In a sheep model 
of smoke inhalation injury along with sepsis induced by pulmonary instillation of Pseudomonas aeruginosa, subsequent treatment with heparin, either aerosolized $(10,000$ units) or intravenous $(5,300$ units $/ \mathrm{kg})$ reduced histologic changes, including pulmonary edema and cast formation. ${ }^{106}$ However, in a sheep model of smoke inhalation injury and extensive cutaneous burns, only a combination of aerosolized heparin and recombinant human antithrombin was found effective in improving pulmonary gas exchange and attenuating lung injury. ${ }^{107}$

To date, the best evidence in support of this therapy is from 2 retrospective, single-center, case-control studies of bronchoscopy-confirmed inhalation injury in both pediatric, ${ }^{103}$ and adult patients. ${ }^{104}$ When compared to controls, pediatric patients treated during the first 7 days of injury with a combination of aerosolized heparin $(5,000$ units) and $3 \mathrm{~mL}$ of $20 \% \mathrm{~N}$-acetylcysteine every $4 \mathrm{~h}$ had significantly reduced atelectasis (69\% vs $42 \%$, respectively), reintubation rate, (28\% vs $6 \%$, respectively), and mortality (19\% vs $4 \%)$. Similar findings of improved 28-day survival rate (94\% vs 57\%), as well as improved lung injury scores, and chest mechanics were reported in 28 adult patients. ${ }^{104}$ In general, aerosolized heparin therapy has not been associated with increased bleeding risks in patients with inhalation injury. ${ }^{103,105}$ However, a case of clinically important coagulopathy was reported in a pediatric patient with inhalation injury whose clinical course was complicated by disseminated intravascular coagulation. ${ }^{108}$

More recently, a preliminary study investigated the potential usefulness of aerosolized heparin for the management of ARDS from common etiologies such as pneumonia and sepsis. ${ }^{109}$ The rationale for utilizing aerosolized heparin in common causes of ARDS is the same as in smoke inhalation. Acute inflammation induces fibrin deposition, which causes both hyaline membrane formation in the alveolar space and pulmonary capillary microthrombosis. In the prospective, short-term ( $48 \mathrm{~h}$ ), phase I study 109 comparing 4 dose regimens (50,000-400,000 units/d), aerosolized heparin was found to be feasible in terms of drug delivery to the lung parenchyma and was not associated with serious adverse events. However, the potential efficacy of aerosolized heparin to improve pulmonary function was not addressed, and awaits the results of future phase II and phase III studies.

\section{Heliox}

Since the 1980s there has been a resurgence in using helium-oxygen gas mixtures to relieve respiratory distress in non-intubated patients with upper-airway obstruction from croup and post-extubation stridor, ${ }^{110}$ as well as from lower airway obstruction in status asthmaticus, ${ }^{111} \mathrm{COPD},{ }^{112}$ and bronchiolitis. ${ }^{113}$ Most evidence supporting its use has come from low-level studies. ${ }^{114}$ Because heliox does not
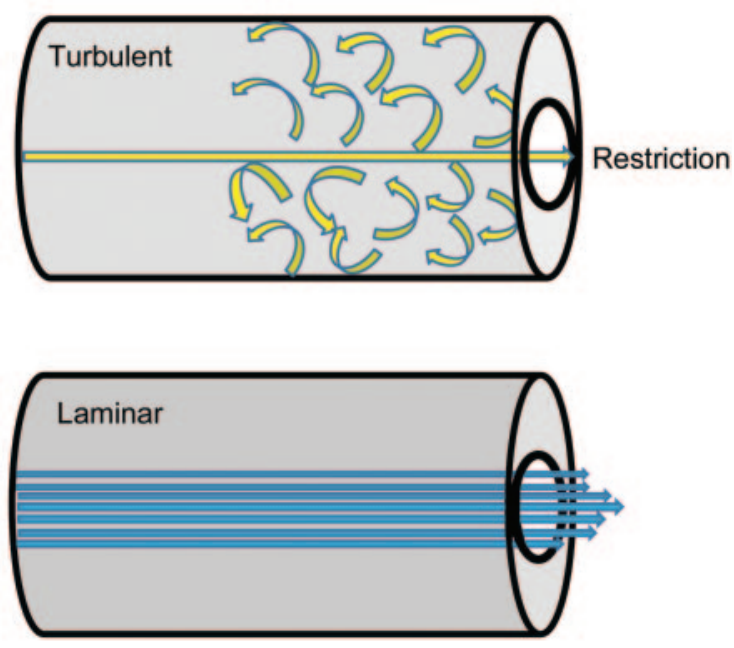

Fig. 3. Representation contrasting the effects of a restriction on gas flow based upon its "kinematic viscosity" (viscosity/density ratio). Restrictions or bifurcations in the airway produce turbulence or "eddies" that disrupt a smooth or "laminar" gas flow and create a high "back-pressure." The degree of turbulence that develops is directly proportional to gas density; the lower the density, the less turbulence. In this illustration, changing the inspired gas mixture from a high oxygen concentration to one with a higher concentration of less-dense helium would tend to convert areas of turbulence in the larger airways toward more of a laminar flow pattern that should result in increased gas flow at a lower driving pressure.

affect the underlying pathophysiology of airway obstruction, it is not surprising that its use in controlled studies has not improved outcomes. ${ }^{110}$ Nevertheless, it provides symptomatic relief and more flexibility in clinical management until the underlying conditions causing airway obstruction can be treated effectively.

Helium is biologically inert; it is essentially insoluble in tissues, and non-reactive with both cellular membranes as well as other common respiratory gases. ${ }^{113}$ The primary mechanism by which heliox works is the fact that helium is $86 \%$ less dense than air $(0.179$ vs $1.293 \mathrm{~g} / \mathrm{L}$, respectively), which reduces turbulence, thus decreasing airways resistance and work of breathing. ${ }^{115}$ Turbulence is characteristic of gas flow in the first 10 generations of human airways because of their branching architecture. ${ }^{112}$

Compared to air $/ \mathrm{O}_{2}$ gas mixtures, helium $/ \mathrm{O}_{2}$ mixtures have only marginally increased viscosity, but substantially lower density. This is referred to as "kinematic viscosity" or the viscosity/density ratio. Higher kinematic viscosity reduces the Reynolds number (that expresses the relationship of kinetic and viscous forces influencing gas flow) and converts areas of turbulent flow within the respiratory tract toward laminar flow (Fig. 3). ${ }^{111}$ In addition, the lower density of helium promotes $\mathrm{CO}_{2}$ elimination by altering the binary diffusion coefficient for intrapulmonary gas mixtures. ${ }^{116}$ 
One of the first reports on the incorporation of heliox during invasive mechanical ventilation was by Gluck et al, ${ }^{116}$ who described rapid and impressive reductions in both peak airway pressure (mean of $33 \mathrm{~cm} \mathrm{H}_{2} \mathrm{O}$ ) and $\mathrm{P}_{\mathrm{aCO}_{2}}$ (mean of $36 \mathrm{~mm} \mathrm{Hg}$ ) in 7 patients in status asthmaticus ventilated with a helium/oxygen mixture of $60 / 40 \%$. Additional studies have reported similar results of reduced peak inspiratory pressures and improved gas exchange, ${ }^{117}$ as well as reduced intrinsic PEEP and work of breathing ${ }^{112}$ when heliox mixtures are used during mechanical ventilation.

In neonates with meconium aspiration, pressure control ventilation with heliox was associated with significant improvements in oxygenation, but only nonsignificant trends toward increased tidal volume and peak expiratory flow. ${ }^{118}$ In a pediatric case of extraordinarily severe ARDS, heliox was used in conjunction with high frequency jet ventilation, which resulted in a rapid improvement in ventilation, as $\mathrm{P}_{\mathrm{aCO}_{2}}$ decreased from 57 to $34 \mathrm{~mm} \mathrm{Hg.}{ }^{119}$ Heliox also increases aerosol deposition in the lung periphery and therefore may improve the effectiveness of bronchodilator therapy. ${ }^{115}$ This has been supported indirectly by studies reporting improved pulmonary function and lower dyspnea scores when bronchodilator therapy with jet nebulizers are powered by heliox. ${ }^{112}$

When clinically acceptable gas exchange can be achieved with a reasonable degree of lung-protection, the costs associated with heliox do not justify its routine use during mechanical ventilation for patients with obstructive lung disease unless there exists profound air-trapping in the presence of hypotension and severe acidosis. Heliox is a useful tool in the clinical armamentarium; however, it should be reserved for patients with severe acute respiratory failure from obstructive lung diseases.

\section{Summary}

The clinical evidence reviewed in this paper suggests that:

First, interfacing IPV with pressure-regulated modes of ventilation may benefit patients with either inhalation injuries or copious thick secretions, whereas artificial coughing with a mechanical insufflation-exsufflation device appears to be effective in patients with neuromuscular disease.

Second, of all inhaled drug therapies currently being investigated, probably none is more important than clearly determining whether aerosolized antibiotics should be used to treat VAP, particularly VAP caused by MDR pathogens resistant to traditional systemic treatment. However, the lack of a definitive phase III RCT, along with the potential risk of inadvertent promotion of MDR microorganisms, prevents advocating the general use of aerosolized antibiotic therapy for the treatment of VAP/VAT.
Third, INO or aerosolized $\mathrm{PGI}_{2}$ therapy should be restricted either to support pulmonary gas exchange in cases of severe ARDS or in the treatment of severe pulmonary hypertension. Although both therapies are strictly supportive and have not been shown to improve outcomes, they may "buy time" to allow definitive therapy to work.

Fourth, very low level clinical evidence suggests that inhaled anticoagulants and oxygen radical scavengers may promote bronchial hygiene and reduce inflammation in ARDS induced by smoke inhalation injury.

Finally, heliox is a useful tool in the clinical armamentarium. But because of its cost, heliox should be reserved for patients with severe acute respiratory failure from obstructive lung diseases.

In this era of evidence-based practice there is justifiable hesitancy toward advocating therapies lacking sufficiently strong clinical data to support their use. Nowhere does this seem more applicable than to the use of adjunctive therapies during mechanical ventilation. Most adjunctive therapies described here are incapable of reversing the underlying pathology under conditions of severe critical illness or trauma (eg, ARDS and overwhelming infection or injury). However, these therapies appear to be useful in supporting the patient until definitive treatment can be undertaken and given sufficient time to work. From a purely practical perspective, it also is apparent that limitations (both financial resources and perceived relative importance) will prevent the undertaking of large RCTs sufficient to provide definitive answers to many of the clinical issues highlighted here.

Therefore, in the absence of compelling evidence, how should clinicians approach the incorporation of adjunctive therapies during mechanical ventilation? A reasonable approach to unproven therapies, such as those described above, might be that they are: used with caution and circumspect enthusiasm; used conservatively with clearly established indications and guidelines or protocols for implementation as well as discontinuation; monitored carefully through ongoing quality assurance projects that routinely reassess the risk and cost-to-benefit ratio; and willingly abandoned if compelling evidence arises (either internally, or through peer-reviewed publications) strongly suggesting harm or ineffectiveness.

\section{REFERENCES}

1. Toussaint M, DeWin H, Steens M, Soudon P. Effect of intrapulmonary percussive ventilation on mucus clearance in Duchenne muscular dystrophy patients: a preliminary report. Respir Care 2003; 48(10):940-947.

2. Cioffi WG, Graves TA, McManus WF, Pruitt BA. High-frequency percussive ventilation in patients with inhalation injury. $\mathrm{J}$ Trauma 1989;29(3):350-354.

3. Davis K, Hurst JM, Branson RD. High frequency percussive ventilation. Prob Respir Care 1989;2(1):39-47. 


\section{Adjunct Therapies During Mechanical Ventilation}

4. Reper P, Dankaert F, van Hille F, van Laeke P, Duinslaeger L, Vanderkelen A. The usefulness of combined high-frequency percussive ventilation during acute respiratory failure after smoke inhalation. Burns 1998;24(1):34-38.

5. Reper P, Wilbaux O, van Laeke P, Vandeenen D, Duinslaeger L, Vanderkelen A. High frequency percussive ventilation and conventional ventilation after smoke inhalation: a randomized study. Burns 2002;28(5):503-508.

6. Freitag L, Schroer M,Brenne J. High-frequency oscillators with adjustable waveforms: practical aspects. Br J Anaesth 1989;63(7): 38S-43S

7. Freitag L, Long WM, Kim CS, Wanner A. Removal of excessive bronchial secretions by asymmetric high-frequency oscillations. J Appl Physiol 1989;67(2):614-619.

8. Kim CS, Rodriguez CR, Eldridge MA, Sackner MA. Criteria for mucus transport in the airways by two-phase gas liquid flow mechanism. J Appl Phsyiol 1986;60(3):901-907.

9. Tomkiewicz RP, Biviji A, King M. Effects of oscillating air flow on the rheologic properties and clearibility of mucous gel simulants. Biorheology 1994;31(5):511-520.

10. King M, Phillips DM, Gross D, Vartian V, Chang HK, Zidulka A. Enhanced tracheal mucus clearance with high frequency chest wall compression. Am Rev Respir Dis 1983;128(3):511-515.

11. George RJ, Johnson MA, Pavia D, Agnew JE, Clarke SW, Geddes DM. Increase in mucociliary clearance in normal man induced by oral high-frequency oscillation. Thorax 1985;40(6):433-437.

12. Clinkscale D, Spihlman K, Watta P, Rosenbluth D, Koellef MH. A randomized trial of conventional chest physical therapy versus highfrequency chest wall compressions in intubated and non-intubated adults. Respir Care 2012;57(2):221-228.

13. Lucangelo U, Antonaglia V, Zin WA, Confalonieri M, Borelli M, Columban M, et al. High-frequency percussive ventilation improves perioperatively clinical evolution in pulmonary resection. Crit Care Med 2009;37(5):1663-1669.

14. Antonaglia V, Lucangelo U, Zin WA, Peratoner A, DeSimoni L, Capitanio G, et al. Intrapulmonary percussive ventilation improves the outcome of patients with acute exacerbation of chronic obstructive pulmonary disease using a helmet. Crit Care Med 2006;34(12): 2940-2945.

15. Deakins K, Chatburn RL. A comparison of intrapulmonary percussive ventilation and conventional chest physiotherapy for the treatment of atelectasis in the pediatric patient. Respir Care 2002;47(10): 1162-1167.

16. Reper P, van Looy K. Chest physiotherapy using intrapulmonary percussive ventilation to treat persistent atelectasis in hypoxic patients after smoke inhalation. Burns 2013;39(1):192-193.

17. Tsuruta R, Kasaoka S, Okabayashi K, Maekawa T. Efficacy and safety of intrapulmonary percussive ventilation superimposed on conventional ventilation in obese patients with compression atelectasis. J Crit Care 2006;21(4):328-332.

18. Clini EM, Antoni FD, Vitacca M, Crisafulli E, Paneroni M, ChezziSilva $\mathrm{S}$, et al. Intrapulmonary percussive ventilation in trachotomized patients: a randomized controlled trial. Intensive Care Med 2006;32(12):1994-2001

19. Chung KK, Wolf SE, Renz EM, Allan PF, Aden JK, Merrill GA, et al. High-frequency percussive ventilation and low $\mathrm{V}_{\mathrm{T}}$ ventilation in burns: a randomized controlled trial. Crit Care Med 2010;38(10): 1970-1977.

20. Eastman A, Holland D, Higgins J, Smith B, Delagarza J, Olson C, et al. High-frequency percussive ventilation improves oxygenation in trauma patients with acute respiratory distress syndrome: a retrospective review. Am J Surg 2006;192(2):191-195.

21. Salim A, Miller K, Dangleben D, Cipolle M, Pasquale M. Highfrequency percussive ventilation: an alternative mode of ventilation for head-injured patients with adult respiratory distress syndrome. J Trauma 2004;57(3):542-546.

22. Velmahos GC, Chan LS, Tatevossian R, Cornwell EE, Dougherty WR, Escudero J, Demetriades D. High-frequency percussion ventilation improves oxygenation in patients with ARDS. Chest 1999; 116(2):440-446.

23. Paulsen SM, Killyon GW, Barillo DJ. High-frequency percussion ventilation as a salvage modality in adult respiratory distress syndrome. Am Surg 2002;68(10):852-856.

24. Salim A, Martin M. High-frequency percussive ventilation. Crit Care Med 2005;33(3):S241-S245.

25. Barach AL, Beck GL. Exsufflation with negative pressure. Arch Intern Med 1954;93(6):825-841.

26. Homnick DM. Mechanical insufflation-exsufflation for airway mucus clearance. Respir Care 2007;52(10):1296-1305.

27. Gomez-Merino E, Bach JR. Duchenne muscular dystrophy. Prolongation of life by noninvasive ventilation and mechanically assisted cough. Am J Phys Med Rehabil 2002;81(6):411-415.

28. Coplin WM, Pieson DJ, Cooley KD, Newell DW, Rubenfeld GD. Implications of extubation delay in brain-injured patients meeting standard weaning criteria. Am J Respir Crit Care Med 2000;161(5): 1530-1536.

29. Khamiees M, Raju P, DeGirolamo A, Amoateng-Adjepong Y, Manthous CA. Predictors of extubation outcome in patients who have successfully completed a spontaneous breathing trial. Chest 2001; 120(4):1262-1270.

30. Epstein SK, Ciubotaru RL, Wong JB. Effect of failed extubation on the outcome of mechanical ventilation. Chest 1997;112(1):186-192.

31. Rothaar RC, Epstein SK. Extubation failure: magnitude of the problem, impact on outcomes, and prevention. Curr Opin Crit Care 2003;9(1):59-66.

32. Vianello A, Arcaro G, Braccioni F, Gallan F, Marchi MR, Chizio $\mathrm{S}$, et al. Prevention of extubation failure in high-risk patients with neuromuscular disease. J Crit Care 2011;26(5):517-524.

33. Goncalves MR, Honrado T, Winck JC, Paiva JR. Effects of mechanical insufflation-exsufflation in preventing respiratory failure after extubation: a randomized controlled trial. Crit Care 2012; 16(2):R48.

34. Rodriguez AME, Pravinkumar E. Mechanical insufflation-exsufflation and prevention of post-extubation acute respiratory failure: most welcome but must be used cautiously in critically ill patients. Crit Care 2012;16(3):431.

35. MacIntyre NR, Silver RM, Miller CW, Schuler F, Coleman RE. Aerosol delivery in intubated, mechanically ventilated patients. Crit Care Med 1985;13(2):81-84.

36. Ari A, Fink JB. Factors affecting bronchoodilator delivery in mechanically ventilated adults. Nursing Crit Care 2010;15(4):192-203.

37. Fuller HD, Dolovitch MB, Posmituck G, Pack WW, Newhouse MT. Pressurized aerosol versus jet aerosol delivery to mechanically ventilated patients. Comparison of dose to the lungs. Am Rev Respir Dis 1990;141(2):440-444.

38. Emberger JS, Brown JM, Killian L. Cost reduction using Aeroneb Solo in a medical ICU ventilator population [abstract]. Respir Care 2011;56(10):1700.

39. O'Riordan TG, Greco MJ, Perry RJ, Smaldone GC. Nebulizer function during mechanical ventilation. Am Rev Respir Dis 1992;145(5): 1117-1122.

40. Dhand R, Guntur VP. How best to deliver aerosol medications to mechanically ventilated patients. Clin Chest Med 2008;29(2):277296.

41. Duarte AG. Inhaled bronchodilator administration during mechanical ventilation. Respir Care 2004;49(6):623-634. 


\section{Adjunct Therapies During Mechanical Ventilation}

42. Dhand R, Jubran A, Tobin MJ. Bronchodilator delivery by metereddose inhaler in ventilator-supported patients. Am J Respir Crit Care Med 1995;151(6):1827-1833.

43. Rau JL, Dunlevy CL, Hill RL. A comparison of inline PMDI actuators for delivery of a beta agonist and a corticosteroid with a mechanically-ventilated lung model. Respir Care 1998;43(9):705712.

44. Fink JB, Dhand R, Grychowski J, Fahey PJ, Tobin MJ. Reconciling in-vitro and in-vivo measurements of aerosol delivery from a metered dose inhaler during mechanical ventilation, and defining efficiency enhancing factors. Am J Respir Crit Care Med 1999;159(1): 63-68.

45. Lin HL, Fink JB, Zhou Y, Cheng YS. Influence of moisture accumulation in in-line space or on delivery of metered dose inhaler through mechanical ventilation. Respir Care 2009;54(10):13361341.

46. Diot P, Morra L, Smaldone GC. Albuterol delivery in a model of mechanical ventilation. Comparison of metered-dose inhaler and nebulizer efficiency. Am J Respir Crit Care Med 1995;152(4):13911394.

47. O'Doherty MJ, Thomas SH, Page CJ, Treacher DF, Nunan TO. Delivery of a nebulized aerosol to a lung model during mechanical ventilation. Effects of ventilator settings and nebulizer type, position and volume of fill. Am Rev Respir Dis 1992;146(2):383-388.

48. Harvey CJ, O’Doherty MJ, Page CJ, Thomas SH, Nunan TO, Treacher DF. Effect of a spacer on pulmonary aerosol deposition from a jet nebulizer during mechanical ventilation. Thorax 1995; 50(1):50-53.

49. Miller DD, Amin MM, Palmer LB, Shah AR, Smaldone GC. Aerosol delivery and modern mechanical ventilation. Am J Respir Crit Care Med 2003;168(10):1205-1209.

50. Alvine GF, Rodgers P, Fitzsimmons KM, Aherns RC. Disposable jet nebulizers. How reliable are they? Chest 1992;101(2):316-319.

51. Hughes JM, Saez J. Effects of nebulizer mode and position in a mechanical ventilator circuit on dose efficiency. Respir Care 1987; 32(12):1131-1135.

52. McPeck M, O'Riordan TG, Smaldone GC. Predicting aerosol delivery to intubated patients: influence of choice of mechanical ventilator on nebulizer efficiency. Respir Care 1993;38(8):887-895.

53. Harvey CJ, O’Doherty MJ, Page CJ, Thomas SH, Nunan TO, Treacher DF. Comparison of jet and ultrasonic nebulizer pulmonary aerosol deposition during mechanical ventilation. Eur Respir J 1997; 10(4):905-909.

54. Phillips GD, Millard FJC. The therapeutic use of ultrasonic nebulizers in acute asthma. Respir Med 1994;88(5):387-389.

55. Yeo LY, Friend JR, McIntosh MP, Meeusen EN, Morton DA. Ultrasonic nebulization platforms for pulmonary drug delivery. Expert Opin Drug Deliv 2010;7(6):663-679.

56. Steckel H, Eskandar F. Factors affecting aerosol performance during nebulization with jet and ultrasonic nebulizers. Eur J Pharm Sci 2003;19(5):443-455.

57. Ari A, Telli O, Harwood R, Sheard MM, Aljamhan EA, Fink JB. Influence of nebulizer type, position and bias flow on aerosol drug delivery in simulated pediatric and adult lung models during mechanical ventilation. Respir Care 2010;55(7):845-851.

58. Chastre J, Fagon JY. Ventilator-associated pneumonia. Am J Respir Crit Care Med 2002;165(7):867-903.

59. American Thoracic Society; Infectious Diseases Society of America. Guidelines for the management of of adults with hospitalacquired, ventilator-associated, and healthcare-associated pneumonia. Am J Respir Crit Care Med 2005;171(4):388-416.

60. Palmer LB. Aerosolized antibiotics in the intensive care unit. Clin Chest Med 2011;32(3):559-574.
61. Rello J, Mariscal D, March F, Jubert P, Sanchez F, Valles J, Coll P. Recurrent Pseudomonas aeruginosa pneumonia in ventilated patients: relapse or reinfection? Am J Respir Crit Care Med 1998; 157(3):912-916.

62. Palmer LB. Aerosolized antibiotics in critically-ill ventilated patients. Curr Opin Crit Care 2009;15(5):413-418.

63. Kallet RH, Quinn T. The role of the gastrointestinal tract in development of ventilator-associated pneumonia. Respir Care 2005;50(7): 910-923.

64. Craven DE, Hjalmarson KI. Ventilator-associated tracheobronchitis and pneumonia: thinking outside the box. Clin Infect Dis 2010; 51(Suppl 1):S59-S66.

65. O'Riordan TG. Inhaled antimicrobial therapy: from cyctic fibrosis to the flu. Respir Care 2000;45(7):836-845.

66. Mohr AM, Sifri ZC, Horng HS, Sadek R, Savetamal A, Hauser CJ, Livingston DH. Use of aerosolized aminoglycosides in the treatment of gram-negative ventilator-associated pneumonia. Surg Infect 2007;8(3):349-357.

67. Palmer LB, Smaldone GC, Chen JJ, Baram D, Duan T, Monteforte $\mathrm{M}$, et al. Aerosolized antibiotics and ventilator-associated tracheobronchitis in the intensive care unit. Crit Care Med 2008;36(7): 2008-2013.

68. Michalopoulos A, Fotakis D, Virtzili S, Vletsas C, Raftopoulou S, Mastora Z, Falagas ME. Aerosolized colistin as adjunctive treatment of ventilator-associated pneumonia due to multidrug-resistant Gram negative bacteria: a prospective study. Respir Med 2008; 102(3):407-412.

69. Ghannam DE, Rodriguez GH, Raad II, Safdar A. Inhaled aminoglycosides in cancer patients with ventilator-associated Gram-negative bacterial pneumonia: safety and feasibility in the era of escalating drug resistance. Eur J Clin Microbiol Infect Dis 2009;28(3): 253-259.

70. Czosnowski QA, Wood GC, Magnotti LJ, Croce MA, Swanson JM, Boucher BA, Fabian TC. Adjunctive aerosolized antibiotics for treatment of ventilator-associated pneumonia. Pharmacotherapy 2009;29(9):1054-1060.

71. Lin C-C, Liu T-C, Kuo C-F, Liu C-P, Lee C-M. Aerosolized colistin for the treatment of multidrug-resistant Acinetobacter baumannii pneumonia: experience in a tertiary care hospital in Northern Taiwan. J Microbiol Immunol Infect 2010;43(4):323-331.

72. Lu Q, Yang J, Gutierrez C, Aymard G, Rouby J-J, and the Nebulized Antibiotics Study Group. Nebulized ceftazidime and amikacin in ventilator-associated pneumonia caused by Pseudomonas aeruginosa. Am J Respir Crit Care Med 2011;184(1):106-115.

73. Arnold HM, Sawyer AM, Kollef MH. Use of adjunctive aerosolized antimicrobial therapy in the treatment of Pseudomonas aeruginosa and Acinetobacter baumannii ventilator-associated pneumonia. Respir Care 2012;57(8):1226-1233.

74. LeConte P, Potel G, Clemente E, Legras A, Villers D, Bironneau E, et al. Administration of tobramycin aerosols in patients with nosocomial pneumonia: a preliminary study. Presse Med 2000;29(2): 76-78.

75. Wood GC, Boucher BA, Croce MA, Hanes SD, Herring VL, Fabian TC. Aerosolized ceftazidime for prevention of ventilator-associated pneumonia and drug effects on the pro-inflammatory response in critically-ill trauma patients. Pharmacotherapy 2002;22(8):972-982.

76. Claridge JA, Edwards NM, Swanson J, Fabian TC, Weinberg JA, Wood GC, Croce MA. Aerosolized ceftazidime prophylaxis against ventilator-associated pneumonia in high-risk trauma patients: results of a double-blind randomized study. Surg Infect 2007;8(1): 83-90.

77. Hallal A, Cohn SM, Namias N, Habib F, Baracco G, Manning RJ et.al. Aerosolized tobramycin in the treatment of ventilator-associated pneumonia: a pilot study. Surg Infect 2007;8(1):73-81. 


\section{Adjunct Therapies During Mechanical Ventilation}

78. Cook DJ, Walter SD, Cook RJ, Griffith LE, Guyatt GH, Leasa D, et.al. Incidence of and risk factors for ventilator-associated pneumonia in critically-ill patients. Ann Intern Med 1998;129(6):433440.

79. Klastersky J, Huysmans E, Weerts D, Daneau D. Endotracheally administration of gentamycin for the prevention of infections of the respiratory tract in patients with tracheostomy: a double-blind study. Chest 1974;65(6):650-654.

80. Feeley TW, du Moulin GC, Hedley-Whyte J, Bushnell LS, Gilbert JP, Feingold DS. Aerosolized polymyxin and pneumonia in seriously ill patients. N Engl J Med 1975;293(10): 471-475.

81. Bigatello LM, Hurford WE, Kacmarek RM, Roberts JD, Zapol WM. Prolonged inhalation of low concentrations of nitric oxide in patients with sever adult respiratory distress syndrome. Anesthesiology 1994;80(4):761-770.

82. Walmrath D, Schneider T, Pilch J, Grimminger F, Seeger W. Aerosolized prostacyclin in adult respiratory distress syndrome. Lancet 1993;342(8877):961-962.

83. Camamo JM, McCoy RH, Erstad BL. Retrospective evaluation of inhaled prostaglandins in patients with acute respiratory distress syndrome. Pharmacotherapy 2005;25(2):184-190.

84. Bein T, Metz C, Cornelius K, Sendtner E, Pfeifer M. Cardiovascular and pulmonary effects of aerosolized prostacyclin administration in severe respiratory failure using a ventilator nebulization system. J Cardiovasc Pharmacol 1996;27(4):583-586.

85. Domenighetti G, Stricker H, Waldispuehl B. Nebulized prostacyclin (PGI2) in acute respiratory distress syndrome: impact of primary (pulmonary injury) and secondary (extrapulmonary injury) disease on gas exchange response. Crit Care Med 2001;29(1):5762

86. Siobal MS, Hess DR. Are inhaled vasodilators useful in acute lung injury and acute respiratory distress syndrome? Respir Care 2010; 55(2):144-157.

87. Dellinger RP, Zimmerman JL, Taylor RW, Straube RC, Hauser DL, Criner GJ, et al. Effects of inhaled nitric oxide in patients with acute respiratory distress: results of a randomized phase II trial. Inhaled Nitric Oxide in ARDS Study Group. Crit Care Med 1998;26(1): 15-23.

88. Michael JR, Barton RG, Saffle JR, Mone M, Markewitz BA, Hillier $\mathrm{K}$, et al. Inhaled nitric oxide versus conventional therapy: effect on oxygenation in ARDS. Am J Respir Crit Care Med 1998;157(5): 1372-1380.

89. Lundin S, Mang H, Smithes M, Stenqvist O, Frostell C. Inhalation of nitric oxide in acute lung injury: results of a European multicentre study . European Study Group of Inhaled Nitric Oxide. Intensive Care Med 1999;25(9):911-919.

90. Mehta S, Simms HH, Levy MM, Hill NS, Schwartz W, Nelson D, et al. Inhaled nitric oxide improves oxygenation acutely but not chronically in acute respiratory distress syndrome: a randomized controlled trial. J Appl Res 2001;1(2):73-84.

91. vanHeerden PV, Barden A, Michalopoulos N, Bulsara MK, Roberts BL. Dose-response to inhaled aerosolized prostacyclin for hypoxemia due to ARDS. Chest 2000;117(3):819-827.

92. Pappert D, Busch T, Gerlach H, Lewandowski K, Radermacher P, Rossaint R. Aerosolized prostacyclin versus inhaled nitric oxide in children with severe acute respiratory distress syndrome. Anesthesiol 1995;82(6): 1507-1511.

93. vanHeerden PV, Webb SAR, Hee G, Corkeron M, Thompson WR. Inhaled aerosolized prostacyclin as a selective pulmonary vasodilator for the treatment of severe hypoxemia. Anaesth Intensive Care 1996;24(1):87-90.
94. Siobal MS, Kallet RH, Pittet J-F, Warnecke EL, Kraemer RW, Venkayya RV, Tang JF. Description and evaluation of a delivery system for aerosolized prostacyclin. Respir Care 2003;48(8):742753.

95. McMillen JC, Burke CF, Dhingra A, Dudney TM, Faircloth BE. Use of inhaled epoprostenol in patients with H1N1 influenza-associated acute respiratory distress syndrome: a case series. Ann Pharmacother 2011;45(5):e25.

96. Ciencewicki J,Trivedia S, Kleeberger SR. Oxidants in the pathogenesis of lung diseases. J Allergy Clin Immunol 2008;122(3):456468.

97. Haber O, Kleen M, Zwissler B, Pusch R, Welte M, Vogelmeier C, Kempter B, et al. Inhalation of prostacyclin (PGI2) for 8 hours does not produce signs of acute pulmonary toxicity in healthy lambs. Intensive Care Med 1996;22(11):426-433.

98. vanHeerden PV, Caterina P, Filion P, Spagnolo DV, Gibbs NM. Pulmonary toxicity of inhaled aerosolized prostacyclin therapy - an observational study. Anaesth Intensive Care 2000;28(2):161-166.

99. Thompson PB, Herndon DN, Taber DL, Abston S. Effect on mortality of inhalation injury. J Trauma 1986;26(2):163-165.

100. Hollingsed TC, Saffle JR, Barton RG, Craft WB, Morris SE. Etiology and consequences of respiratory failure in thermally injured patients. Am J Surg 1993;166(6):592-596.

101. Zikria BA, Weston GC, Chodoff M, Ferrer JM. Smoke and carbon monoxide poisoning in fire victims. J Trauma 1972;12(8):641-645.

102. Chong SJ, Song C, Tan TW, Kusumawijaja G, Chew KY. Multivariate analysis of burn patients in the Singapore General Hospital Burn Centre (2003-2005). Burns 2009;35(2):215-220.

103. Desai MH, Mlcak R, Richardson J, Nichols R, Herndon DN. Reduction in mortality in pediatric patients with inhalation injury with aerosolized heparin/acetylcystine therapy. J Burn Care Rehabil 1998; 19(3):210-212.

104. Miller AC, Rivero A, Ziad S, Smith DJ, Elamin EM. Influence of nebulized unfractionated heparin and $\mathrm{N}$-acetylcysteine in acute lung injury after smoke inhalation injury. J Burn Care Res 2009;30(2): 249-256.

105. Yip LY, Lim YF, Chan HN. Safety and potential anticoagulant effects of nebulized heparin in burn patients with inhalational injury at Singapore General Hospital Burn Centre. Burns 2011;37(7):11541160.

106. Murakami K, McGuire R, Cox RA, Jodoin MJ, Bjertnaes LJ, Katahira J, et al. Heparin nebulization attenuates acute lung injury in sepsis following smoke inhalation in sheep. Shock 2002;18(3): 236-241.

107. Enkbaatar P, Cox RA, Traber LD, Westphal M, Aimalohi E, Morita $\mathrm{N}$, et al. Aerosolized anticoagulants ameliorate acute lung injury in sheep after exposure to burn and smoke inhalation. Crit Care Med 2007;35(12):2805-2810.

108. Chopra A, Burkey B, Calaman S. A case report of clinically significant coagulopathy associated with aerosolized heparin and acetlycysteine therapy for inhalation injury. Burns 2011;37(7):e73-e75.

109. Dixon B, Santamaria JD, Campbell DJ. A phase 1 trial of nebulized heparin in acute lung injury. Crit Care 2008;12(3):R64.

110. Robinson BRH, Athota KP, Branson RD. Inhalational therapies for the ICU. Curr Opin Crit Care 2009;15(1):1-9.

111. Shiue ST, Gluck EH. The use of helium-oxygen mixtures in the support of patients with status asthmaticus and respiratory acidosis. J Asthma 1989;26(3):177-180.

112. Colebourn CL, Barber V, Young JD. Use of helium-oxygen mixture in adult patients presenting with excacerbations of asthma and chronic obstructive pulmonary disease: a systematic review. Anaesthesia 2007;62(1):34-42.

113. Leit JM, Ducruet T, Gupta V, Cambonie G. Heliox inhalation ther- 
apy for bronchiolitis in infants. Cochrane Database Syst Rev 2010; 14(4):CD006915.

114. Vorwerk C, Coates T. Best evidence topic reports: heliox in croup. Emerg J Med 2008;25(9):365-366.

115. Gentile MA. Inhaled medical gases: more to breathe than oxygen. Respir Care 2011;56(9):1341-1357.

116. Gluck EH, Onorato DJ, Castriotta R. Helium-oxygen mixtures in intubated patients with status asthmaticus and respiratory acidosis. Chest 1990;98(3):693-698.
117. Abd-Allah SA, Rogers MS, Terry M, Gorss M, Perkin RM. Helium-oxygen therapy for pediatric acute severe asthma requiring mechanical ventilation. Pediatr Crit Care 2003;4(3):353-357.

118. Szczapa T, Gadzinowski J. Use of heliox in the management of neonates with meconium aspiration syndrome. Neonatology 2011; 100(3):265-270.

119. Gupta VK, Grayck EN, Cheifetz IM. Heliox administration during high-frequency jet ventilation augments carbon dioxide clearance. Respir Care 2004;49(9):1038-1044.

\section{Discussion}

MacIntyre: In 1995 there was a consensus conference on innovations in mechanical ventilation, ${ }^{1}$ and one of the themes that came from that was that if you had an innovation that was not particularly risky or expensive, the required level of evidence for adopting it could be physiologic or intermediate types of outcomes. In contrast, an innovation with substantial risk or cost would not be recommended without support from a real outcomes study. That's my prologue to asking for your thoughts on INO, which is ridiculously expensive, has only transient benefits, and the RCTs to date have not shown any benefits or positive outcomes of any sort. ${ }^{2}$ The Canadian group ${ }^{3}$ even suggested there was a risk of renal failure. So if INO is both expensive and has risks, why do we even talk about it without the outcome evidence to support its use?

Kallet: A good question. I agree with you; the ethics that you just laid out are clear. It's more of an emotional reaction, but when you're at the bedside in a dire situation and you think you're about to lose someone and you can't get the $\mathrm{P}_{\mathrm{O}_{2}}$ up, the cost/benefit ratio in that situation would, I think, allow the use of INO. If you're not at that point, I would have trouble with it. It gets my dander up when some people at prestigious institutions in the Bay Area (who shall remain nameless) say, "INO doesn't improve outcomes, so we don't use it: period!" I just can't buy into that.
MacIntyre: Sounds pretty reasonable to me.

Kallet: I know. But I think there are individual cases in all these questions of evidence-based medicine. It depends on the individual patient. I agree that INO should be restricted and not used as a general approach, but I think there are individual cases where it may be appropriate. That's my emotional response at the bedside, but I don't promote this.

MacIntyre: I would call David Turner and get some help with ECMO [extracorporeal membrane oxygenation] in that kind of patient.

Turner: We often use INO to help improve stability as a bridge to ECMO. There is often a transient improvement in gas exchange with INO, but if INO is not being used as a bridge to ECMO, an important question is when do you stop?

Kallet: That's a good question, and I wish I knew. We've had the same problem with aerosolized prostacyclin. There's not much research on its pulmonary toxicity, as it is an alkalized solution that's inhaled for several weeks in some of our patients. So when should you begin to wean it down? I thought the same thing when I was touring a hospital that commonly uses ECMO in ARDS patients. There was a patient stabilized on $60 \%$ and PEEP of $10 \mathrm{~cm} \mathrm{H}_{2} \mathrm{O}$ on ECMO, and I asked when do you start weaning off ECMO? They said "professional opinion." It should be protocolized, and at our hos- pital we could do a much better job with this. That's the beauty of protocols: they kick clinicians in the butt and force them to move out of their comfort zone and challenge patients. As a culture we collectively don't do a very good job with that.

Kacmarek: I don't think you gave prostacyclin its due in your presentation. You did mention the data on using it in pulmonary hypertension, but we're using it increasingly in the cardiac surgery arena. The cardiac surgeons, for the most part, find it equivalent to INO, and we have switched to $80 \%$ use of prostacyclin and decreased the use of INO in the cardiac arena. We also use prostacyclin for hypoxemic respiratory failure, but not as much as we use INO. Besides cardiac surgical patients, we see INO used in the pediatric and neonatal ICUs more than anywhere else for respiratory failure, but it tends to be a bridge to ECMO or a poor outcome.

Kallet: You're absolutely right. I did shortchange the presentation on some things about aerosolized prostacyclin, particularly pulmonary hypertension, but my focus was mechanical ventilation.

Kacmarek: I just didn't want cardiac surgeons to read this and get the wrong ideas.

Kallet: We use it. We've seen some incredible cases; in one patient with extreme pulmonary hypertension we gave inhaled prostacyclin and within a few minutes there was a huge 
decrease in central venous pressure and increase in systemic blood pressure.

Marini: I'd like to discuss secretions and ARDS, because I believe we are missing a lot by not paying attention to secretions. Secretions in the smaller airways can plug a lot of channels that would otherwise be open for gas exchange. When you keep a patient motionless, especially in the first few days, secretions are going to collect in the dependent areas. I wonder if it isn't high time for us to be looking at secretion management in patients with ARDS: particularly in primary ARDS, but also in edematous ARDS. The aerosolized heparin, digestive enzymes, et cetera that you talked about may also have a bigger role than we've been allowing them. We may be neglecting important therapies.

Kallet: I agree. Hubmayr did some work looking for recruitment and basically found it was being sloshed back and forth. ${ }^{4}$ It hasn't received enough research emphasis. My own personal experience in some of the devastating hypoxemic cases has usually been severe ARDS complicated by lobar collapse from obstruction. It hasn't been focused on enough, and should be in future research. If the ARDS Network goes into a third iteration, it might be a good prospective RCT for them.

Schmidt: One problem is systemic absorption. We observed substantial blood pressure drops with prostacyclin and with aerosolized antibiotics. With inhaled tobramycin we measured very high tobramycin levels in the blood. So the question is, does it work in the lung, or does it work systemically because we have another way of absorption? I'm not so sure about this; I'm a little bit skeptical.

Kallet: One of the issues with prostacyclin is rain-out of aerosol where it can get into poorly ventilated areas and increase ventilation/perfusion mismatch after a while.

Schmidt: Orblood pressure, because it gets systemically absorbed.

Kacmarek: I think it's also related to dosing. We had problems in our earlier use, when we didn't have the dosing figured out to the extent we have now. We are not seeing the systemic hypotension, particularly in cardiac surgery patients, that we saw earlier. We adjusted the way we administer the drug and the dosage, and we found the right mix between benefit and avoiding adverse effects.

Schmidt: True: much less.

Kallet: It's hard with blood pressure, because we haven't seen the hypotension with long-term inhaled prostacyclin. Granted, it wasn't something we were necessarily looking for, but it wasn't obvious. Since we have a love affair with propofol and everybody's on high doses of propofol, it's harder in the ICU to know what's actually going on. I would think it would be a sustained problem, if aerosolized prostacyclin was being continuously systemically absorbed, we'd get some signal with blood pressure management. It's not something that's been very salient. It may be an issue, I don't disagree with you, Uli, but it's not something that's jumped out at us. And there are so many things going on in the critical care environment it's hard to figure out cause and effect.

Hess: What about tachyphylaxis? One of our pharmacists advocates for increasing the dose-we use epoprostenol-when we have someone on for several days, because you develop some tachyphylaxis and you need to increase the dose.

Kallet: Good point. We haven't looked at that. What I'd say clinically when we have someone on high doses of aerosolized prostacyclin is that we should be doing recruitment or proning. We should do something mechanically to recruit the lung and improve ventilation/perfusion to get them off that drug. It should be something to tide us over, get us over the hump, but I don't think we should rely on it for days at a time. People don't want to prone patients because it's a hassle, and they don't want to do recruitment maneuvers, which they think are dangerous. The drug doesn't appear to be dangerous and the perception is selfperpetuating. The ICU hums along as it always does. Clinicians a lot of times won't challenge themselves and get out of their comfort zone.

Branson: I have a question about IPV. IPV makes perfect physiologic sense to me: it gives you a deep breath and then it creates the mucus flow. What's your feeling about our ability to monitor the actual volumes and airway pressures during IPV?

Kallet: I don't know how you would track that, and I haven't really used IPV. We just started to use it with our burn patients. Do you have any suggestions for monitoring that?

Branson: Dellamonica et al had a paper about the introduction of the IPV device inside the ventilator circuit. ${ }^{5}$ While most of the IPV aficionados will tell you that the phasitron [sliding venturi device that creates the IPV gas pulses] will prevent overpressurization because eventually it will get to where it doesn't entrain, if you set the driving pressure high enough, you can get quite a large tidal volume. That's something to be aware of.

Kallet: Good point.

Blakeman: A few years ago the Centers for Disease Control and Prevention was interested in the effect of aerosolized antibiotics on caregivers. On the walls of patient rooms they found substantial amounts of antibiotics. Can you speak to that? 
Kallet: I was focused on mechanical ventilation studies, and I didn't see that as an issue under those circumstances. The first thing that comes to mind is the administration of TOBI [inhaled tobramycin] in kids with cystic fibrosis, who aren't intubated. When we administered aerosolized pentamidine back in the 1990s, we had a filter on the expiratory circuit.

Blakeman: When we use it in mechanical ventilation, we use TOBI and some colistin, and you can smell the antibiotics, even though we're filtering the ventilator circuit. There is some question of caregivers breathing it in and whether we might create super-bugs.

Kallet: Yes, so wearing an N95 mask during aerosolization-I think in any RCT done with that, it should be an issue: clinician and environmental exposure need to be rigorously tracked. We need to convince people that the benefits outweigh the risks.

Gajic: For cost reasons, in our institution we limited the use of INO for severe hypoxemia or shock in patients with pulmonary hypertension. However, we have a big group of adult congenital heart disease patients who come in with a new sepsis or something like that, and these patients may benefit from INO. We sometimes continue INO after extubation to NIV, to attempt to prevent reintubation, and some patients may pull through. Can inhaled prostacyclin work in that group of patients with severe pulmonary hypertension? Can it be used instead of INO?

Kallet: I think they're using alprostadil.

Gajic: No, you extubate and then you wean it off noninvasively.

MacIntyre: They don't go home with INO?
Gajic: No, but they live in the 80s. The point is that it's a new challenge. Before we restricted INO use for hypoxemic respiratory failure. We say, "If someone really wants to use INO, use inhaled prostacyclin. Neither works, but inhaled prostacyclin is cheaper." For severe pulmonary hypertension, can INO be replaced by inhaled prostacyclin?

Kallet: They're using inhaled alprostadil. Every 8 hours you give a treatment.

Hess: Except it only lasts 2 or 3 hours.

Gajic: In an acute situation can inhaled alprostadil replace INO?

Kallet: I don't see why not.

Gajic: It works as well?

Turner: Yes, potentially.

Gajic: Do you use it for babies?

Turner: I do not have any personal experience with inhaled prostadil instead of INO for acute pulmonary hypertension, but some people are interested in it.

Gajic: When visiting community hospitals, I still see some use of highfrequency jet percussive ventilation for patients with ARDS and secretions. Does anybody here use it, or what do you think about it?

Kallet: We don't use it. We use runof-the-mill lung-protective ventilation.

Turner: We don't routinely use high-frequency percussive ventilation either, but there have been successful reports of its use, especially in burn patients. ${ }^{6,7}$

Gajic: And does it work there?

Turner: Some burn centers use it almost exclusively. There are certainly potential benefits in situations where secretion clearance is a major concern.
Branson: The Army's burn group has used VDV [volumetric diffusive ventilation] for a long time. The original work on that was by Bill Cioffi. The Army burn team uses nothing but VDV for burned soldiers. ${ }^{8}$ Which is not to say that it works any better than anything else; it's what they do and it's their history. Things we've talked about for trying to improve secretions, both VDV and IPV, make perfect sense. The big concern with VDV has always been, like jet ventilation, the humidification. You humidify only the entrained gas, not the gas that's going in the end of the phasitron, which is the majority of gas delivered to the patient, so you can deliver some low humidity unless you're very careful.

\section{REFERENCES}

1. Consensus Conference III: assessing innovations in mechanical ventilator support. Respir Care 1995;40(9):905-1016.

2. Dellinger RP, Zimmerman JL, Taylor RW, Straube RC, Hauser DL, Criner GJ, et al. Effects of inhaled nitric oxide in patients with ARDS: results of a randomized phase II trial. Inhaled Nitric Oxide in ARDS Study Group. Crit Care Med 1998;26(1):15-23.

3. Ferguson ND Inhaled nitric oxide for ARDS. BMJ 2007;334(7597):757-758.

4. Hubmayr RD. Perspective on lung injury and recruitment: a skeptical look at the opening and collapse story. Am J Respir Crit Care Med 2002;165(12):1647-1653.

5. Dellamonica J, Louis B, Lyazidi A, Vargas F, Brochard L. Intrapulmonary percussive ventilation superimposed on conventional ventilation: bench study of humidity and ventilator behavior. Intensive Care Med 2008;34(11):2035-2043.

6. Chung KK, Wolf SE, Renz EM, Allan PF, Aden JK, Merrill GA, et al. High-frequency percussive ventilation and low tidal volume ventilation in burns: a randomized controlled trial. Crit Care Med 2010;38(10): 1970-1977.

7. Starnes-Roubaud M, Bales EA, WilliamsResnick A, Lumb PD, Escudero JA, Chan LS, Garner WL. High frequency percussive ventilation and low $\mathrm{F}_{\mathrm{IO}_{2}}$. Burns 2012; 38(7):984-991.

8. Barillo DJ, Renz EM, Wright GR, Broger KP, Chung KK, Thompson CK, Cancio LC. High-frequency percussive ventilation for intercontinental aeromedical evacuation. Am J Disaster Med 2011;6(6):369-378. 